\title{
Early Childhood Health and the Life Course:The State of the Science and Proposed Research Priorities
}

\section{A Background Paper for the MCH Life Course Research Network}

W. Thomas Boyce and Clyde Hertzman

\begin{abstract}
But Laura lay awake a little while, listening to Pa's fiddle softly playing and to the lonely sound of the wind in the Big Woods. She looked at Pa sitting on the bench by the hearth, the firelight gleaming on his brown hair and beard and glistening on the honey-brown fiddle. She looked at Ma, gently rocking and knitting.

She thought to herself, 'This is now.'

She was glad that the cozy house, and Pa and Ma and the firelight and the music, were now. They could not be forgotten, she thought, because now is now. It can never be a long time ago.
\end{abstract}

Little House in the Big Woods Laura Ingalls Wilder (1932)

\section{Introduction: What's So Special About the Early Years?}

In these lines from the Little House book series recalling her early years in a nineteenth-century pioneer family, Laura Ingalls Wilder evoked what we deem a timeless and evocative, if modestly sentimental, image of childhood: children's dependency upon the reliable and protective presence of parents, children's uniquely vulnera-

\footnotetext{
W. Thomas Boyce $(\bowtie)$

Departments of Pediatrics and Psychiatry, University of California San Francisco, San Francisco, CA, USA e-mail: istom.boyce@ucsf.edu

\section{Hertzman}

Human Early Learning Partnership, School of Population and Public Health, University of British Columbia, Vancouver, BC, Canada
}

ble and consequential sensibilities, their openness to the character and "feel" of the physical and social worlds, and their singular immersion in the present, the moment at hand. The overarching goals of this chapter are to survey extant literature examining evidence for these special susceptibilities of children to social-environmental conditions, to show how variation in life course health development is attributable to interactive differences in constitutional susceptibility and contextual exposure, and to summarize lacunae in our collective vision of how early adversity becomes biologically embedded in the course of individual health development.

Wilder's portrait of early childhood is the same image promulgated in the eighteenth century writings of Jean Jacque Rousseau, who affirmed children's inherent goodness and receptivity to the social world and educational institutions' responsibility never to impede children's natural independence and curiosity (see Émile, or Treatise 
on Education). Such an image of childhood is also wholly commensurate with twenty-first century visions of youth as a season of special vulnerability within the human life course health development - a developmental discontinuity from the less susceptible, more defended reaches of adulthood and life in an adult society. Some historians of childhood have claimed that these visions of children's special sentience and fragility are social constructions - products of the temporal and cultural epoch in which we now live. Philippe Ariès in his Centuries of Childhood (Ariès 1962) and Edward Shorter in The Making of the Modern Family (Shorter 1975) argued, for example, that prior to the seventeenth and eighteenth centuries, fewer distinctions were made between children and their adult counterparts in their needs, capacities, and proclivities. They further held that, as a consequence of the extraordinary rates of infant mortality at the time (25-50\%; King 2007), parents were less likely to make strong emotional investments in children. Other scholars have judged such claims hyperbolic, however, discerning evidence for qualitative differentiation between children and adults in ancient Egyptian songs ("Hast thou come to kiss the child?/ I will not let thee kiss him!/ Hast thou come to silence him?/ I will not let thee set silence over him!" (Hrdy 1999)), in the writings of Renaissance Italy and Reformation Germany (King 2007) and in the plays of Shakespeare ("Those that do teach young babes/ Do it with gentle means and easy tasks/ He might ha' chid me so; for, in good faith,/ I am a child to chiding." Romeo and Juliet) (Chedgzoy et al. 2007). Cultural historian Peter Stearns (Stearns 2011) thus maintained that a special affection for and attentiveness to children and children's vulnerability are no inventions or fabrications of modernity.

Nonetheless, ethnogeographer Jared Diamond points to the dramatic variation that exists, even in the contemporary world, among parenting practices emanating from this differentiated and particular view of childhood (Diamond 2012). Both Stearns and Diamond cite, for example, the historical and contemporary practice of swaddling infants as an iconic parenting act that is grounded in deep cultural beliefs about the nature of infancy and childhood, about the relationship of children to parents, and about the fundamental nature of the human child. Hrdy shows how extraordinary differences in mothering behavior have occurred, historically and contemporaneously, as a consequence of sociocultural and economic conditions, despite strong, evolutionarily conserved commonalities in innate maternal responses (Hrdy 1999). Further, Barr et al. (1991) demonstrate that developmental and temporal patterns of infant crying are invariant between North American and !Kung San infants, but parental responses to such crying are highly divergent. Though parenting practices come and go and beliefs regarding the consequences of such practices vary by geography and cultural era, most historical and present human societies have attributed to young children a special susceptibility to the character of the social and physical contexts in which they are reared.

There have also been abiding cultural convictions - crossing geography and time-that the special sensibilities of young children, when exposed to psychological and physical adversities, can produce forms of morbidity extending well beyond the exposure itself, into the domain of adult life. We have strongly held beliefs in the continuities - for better and for worse-between childhood and adulthood. John Milton (16081674) wrote in Paradise Regained that "The childhood shews the man/ As morning shews the day" and William Wordsworth (1770-1850) observed, in My Heart Leaps Up When I Behold, that "The Child is father of the Man." Marcel Proust (1871-1922) described, in Remembrance of Things Past, the sudden, flooding and vivid awareness of a childhood memory in an ordinary moment of adult life:

\footnotetext{
When from a long distant past nothing subsists, after the people are dead, after the things are broken and scattered, taste and smell alone, more fragile but enduring, more unsubstantial, more persistent, more faithful, remain poised a long time, like souls, remembering, waiting, hoping, amid the ruins of all the rest.
}

In the early and mid-twentieth century, these long held beliefs about childhood's capacity for intrusion into the experiences of adult life began 
to find their way into the borderlands of emerging science. Freud famously asserted that neurotic behavior and obsessions manifesting in midadulthood were often linked, without conscious awareness, to experiences of trauma sustained decades before, in very early life (Freud 1940). Biologist and scholar René Dubos invoked "biological Freudianism" to argue that the adverse exposures of childhood can produce lasting neurobiological predispositions that persist even when such exposures are later abated or gone (Dubos et al. 1966). Jerome Kagan (e.g., Brim and Kagan 1980) observed the ways in which human health development is characterized by both constancy and sometimes remarkable discontinuity across developmental periods. Though the experiences of childhood may not overdetermine or dominate the strengths and liabilities of adult life, our cultural heritage avows not only a child's special receptivity to the provisions and predations of its early world but the lifelong echoes of that receptivity, as well.

\section{Susceptibility and Continuity:The Echoes of Childhood}

The now thriving science of how early social experience influences lifelong health and development might be legitimately portrayed as building a scientific foundation for these two longstanding tenets of cultural belief. These are the claims (a) that childhood is imbued with a distinctive susceptibility to the character of the social and physical world and (b) that, partially as a consequence of the former, the exposures of early life - those both damaging and sustaining-continue to exert their effects on health and well-being long beyond the childhood years. John Bowlby thus concluded that the infants of all primate species show an evolutionarily conserved predisposition to form powerful emotional attachments to their mothers, striving to stay close to her side at all times and thereby reducing the risks of abandonment or endangerment (Bowlby 1969). Harlow, Suomi, and col- leagues, in the nonhuman primate equivalent of Bowlby's work with human children, showed that the drive toward early attachment is so strong that, in the mother's absence, an infant macaque will physically and emotionally bond to an inanimate surrogate but with subsequent behavioral aberrations that extend through the infant's lifetime (Harlow et al. 1971). Over the last two decades, Barker and colleagues produced a large body of findings suggesting that chronic, life-threatening cardiovascular disease in mid- to late life is derived from nutritional deficits and impaired growth occurring in very early, even prenatal life (see, e.g., Barker 1990; Barker and Bagby 2005; Bock and Whelan 1991). Kuh and Ben-Shlomo (2004) outlined a "life course approach" to chronic disease epidemiology, assembling convergent evidence for temporally distant relations between markers of childhood deprivation and compromise and indices of chronic morbidity in adult life. The Human Development Program of the Canadian Institute for Advanced Research (CIFAR) showed how population health and developmental science coincide to reveal powerful societal effects on child development and health and how such effects are transcribed into lifetimes of socially partitioned differences in adult disease (Keating and Hertzman 1999). The American Academy of Pediatrics has recently called public attention to the issue of significant, "toxic" stress and adversity in the lives of young children and asserted that many of the chronic disorders of adult life should now be regarded as "developmental disorders," stemming as they do from adverse childhood experiences and events. Abstracting these and other programs of research, three major reports - in the USA (Shonkoff and Phillips 2000), the UK (Marmot 2010), and Canada (Boivin and Hertzman 2012)-have sought and achieved a multidisciplinary consensus that the experiences of early life, dramatically partitioned by aspects of socioeconomic status (SES) and social position, result in societies with widely divergent developmental and health outcomes. Such societies produce visibly and persistently disadvantaged social groups 
whose children follow blighted developmental trajectories, acquire chronic disease and disability more frequently and severely, learn and achieve less well, and live substantially shorter, less adaptive lives.

\section{Constitution, Context, and the Nonrandom Distribution of Morbidity}

Although strong, multinational consensus has been reached on the power and pervasiveness of epidemiologic findings in linking early experience to lifelong disparities in health development and health, urgent and challenging new research questions remain. Among these are the following:

- What is the source of the extensive variability in associations between early adversity and health? Why are some children profoundly affected by early stressors and disadvantage, while others appear to thrive in the face of great risk?

- How does it happen? That is, what are mechanisms and mediators by which early exposures become biologically embedded in development, yielding lifelong differences in health? How does adversity "get into the body," altering long-term pathogenic processes that predispose to disease and disorder?

- What role, if any, do constitutional differences in vulnerability - genetic variation, neurobiological response biases, or enduring temperamental attributes-play in the consequences of early life adversity?

- Does the timing, frequency, and persistence of exposure matter? That is, is there unevenness in the effects of adversity by the age of the child or by the intensity and duration of the exposure?

- Are there transgenerational effects of early social adversity? Are the "iniquities of the father visited upon their children, to the second and third generation" (Exodus 34:7)? Are the traumas of a single generation transmitted into the lives of the next?
Such questions are not just scientifically compelling; they do not simply appeal to our twentyfirst century zeal to understand nuance, contingency, and mechanism. Conceiving and implementing effective societal interventions to mitigate health disparities will be necessarily conditional upon clear and instructive answers. As an organizational approach to these and other life course health development questions, we propose a useful convergence of two fundamental principles emerging from this new science of early childhood experience and development. These are:

Principle 1: Most developmental and health endpoints in human populations are derived from causal interactions between contextual and constitutional factors.

Principle 2: Disordered development and health are nonrandomly distributed by population, space, and time.

Principle 1 affirms a now broadly accepted refutation of earlier claims that maladaptive outcomes are principally genetically or environmentally determined. Incontrovertible evidence now rejects both environmental and genetic determinism and views the genesis of disease as involving a dynamic interplay between environments and genes. Even the simple partitioning of developmental variance into environmental and genetic components falls short of a truly interactive view of the conjoint operation of nurture and nature (Boyce et al. 2012b; Meaney 2010). Importantly, our assertion that causal interactions between contextual and constitutional differences will predominate in the pathogenesis of human morbidities does not entail a claim that no main effects of such differences will be found. Far more research is needed to conclude confidently that gene-environment interplay predominates in the pathogenesis of most human diseases, but such interactive processes appear almost certainly more prevalent and common that was imagined even a decade ago (Dunn et al. 2011; Wright and Christiani 2010). Principle 2 contends, as did Bronfenbrenner's bioecological model (e.g., Bronfenbrenner and Morris 2006), that disorders of health and development are neither evenly nor stochastically distributed 
within human populations and that such disorders are instead informatively clustered by population (both within and across populations), space (both geography and jurisdiction), and time (both developmental and historical). The maldistribution of disorder within human populations signals important and reliable differences in susceptibility to various forms of morbidity and their causal agents. The aggregation of morbidities by space and time extends beyond conventional understandings of epidemicity to include geographic and mobility effects on morbidity and critical periodicity in developmental processes.

A cross-referencing of these Principles 1 and 2 produces the table below, which divides supportive evidential territory into six domains of research: I. social stratification, poverty, and subordination; II. vulnerability, resilience, and neurobiological susceptibility; III. the topography of vulnerability; IV. marginalization and scapegoating; V. history and affliction; and VI. critical periodicity. These six domains codify the contextual and constitutional sources of disease maldistribution, aggregated by population, space, and time. In the sections that follow, we abstract and review each of these arenas of research, which together serve to summarize current and emerging findings on the lifetime effects of early childhood exposures. The crosscutting, confluent cell below the six domains designates a section on interactions between context and constitution, in the form of gene-environment interplay, and their role in the biological embedding of early social adversities and the emergence of what has been called "the social brain." Finally, as indicated in table's bottom cell, we conclude with a specification of missing areas of study, unaddressed questions, and an agenda for future work on the developmental origins of life morbidities (Table 1).

\section{$4 \quad$ Six Domains of Early Developmental Research}

\subsection{Social Stratification, Poverty, and Subordination}

Among the most well-replicated, populationlevel findings in all of the child health services research is illustrated in Fig. 1. Within childhood populations from a broad diversity of settings, cultures, and societies, a subgroup of 15-20\% sustain over half of the populations' morbidities, both biomedical and psychiatric, and are responsible for over half of the health-care utilization (Boyce 1985; Diaz et al. 1986). The public health implications of this finding are self-evident: if we could explain and address the disproportionate morbidity carried by this small subgroup of childhood populations, we might prevent over half of the population's diseases, injuries, and disorders.

The search for an explanation for this highly nonrandom distribution of human morbidity begins and ends with the phenomenon of social stratification, that is, the hierarchical social organization that characterizes much of invertebrate to

Table 1 Domains of existing, anticipated, and needed research, organized by Principles 1 and 2

\begin{tabular}{|c|c|c|c|}
\hline & & \multicolumn{2}{|c|}{$\begin{array}{l}\text { Principle 1: Developmental and health outcomes stem from } \\
\text { interactions between }\end{array}$} \\
\hline & & Context & Constitution \\
\hline \multirow{5}{*}{$\begin{array}{l}\text { Principle 2: Disordered } \\
\text { outcomes are } \\
\text { nonrandomly } \\
\text { distributed by }\end{array}$} & Population & $\begin{array}{l}\text { I. Social stratification, poverty, } \\
\text { and subordination }\end{array}$ & $\begin{array}{l}\text { II. Vulnerability, resilience, and } \\
\text { neurobiological susceptibility }\end{array}$ \\
\hline & Space & $\begin{array}{l}\text { III. The topography of } \\
\text { vulnerability }\end{array}$ & $\begin{array}{l}\text { IV. Marginalization and } \\
\text { scapegoating }\end{array}$ \\
\hline & Time & V. History and affliction & VI. Critical periodicity \\
\hline & & \multicolumn{2}{|c|}{$\begin{array}{l}\text { Interactions between context and constitution, } \\
\text { gene-environment interplay }\end{array}$} \\
\hline & & \multicolumn{2}{|c|}{ An Agenda for Future Research } \\
\hline
\end{tabular}




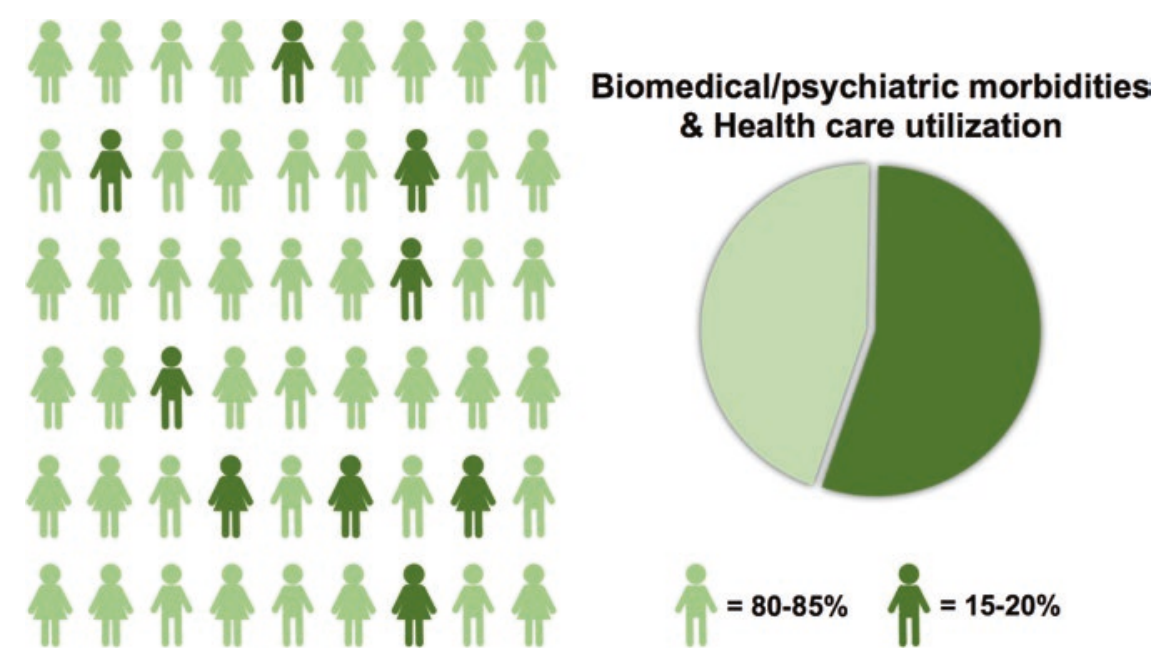

Fig. 1 The nonrandom distribution of biomedical and psychiatric morbidities in child populations

vertebrate phylogeny and manifests as SES within human societies. SES constitutes the single, most powerful epidemiologic determinant of virtually all forms of morbidity, a predictor so potent that we question the authenticity of other associations failing to adjust for SES (Adler et al. 1993, 1994). Beginning early in life, impoverished children and families sustain higher rates of virtually every form of human malady: from low birth weight (Blumenshine et al. 2010) to traumatic injury (Brown 2010), from infectious disease (Dowd et al. 2009) to dental caries (Boyce et al. 2010), and from developmental disability (Msall et al. 1998) to poorer academic achievement (Kawachi et al. 2010). Socioeconomic stratification of developmental psychopathology, moreover, which often emerges in preclinical form in the middle childhood years, exerts lasting influences on academic achievement, employment success, interpersonal relationships, and lifelong wellbeing (Offord 1995; U.S. Department of Health and Human Services 2011). Figures 2 and 3 show how poor and neglected populations bear disproportionate burdens of disease and disorder throughout the life span (see Marmot 2010) - Fig. 2 showing the graded association between SES and socioemotional adjustment from middle childhood through adolescence and Fig. 3 revealing the same relation with chronic disease at each stage of the life course.
Despite this universality and potency of societal disparities in health, it is only recently that SES has become itself a focus of serious scientific study (Syme 2008). New studies of the SES antecedents of population morbidities have recognized the extended influence of childhood social status on adult disease, even after controlling for SES in adulthood (Cohen et al. 2010; Galobardes et al. 2004; Lawlor et al. 2006). Such evidence for lifelong effects of early disadvantage is rendered still more compelling by research documenting the developmental origins of adult health and disease (Gluckman et al. 2005, 2009) and by epidemiologic work revealing systematic differences in nutrition (Khan and Bhutta 2010), access to medical care (Houweling and Kunst 2010), and physical environmental exposures (Gump et al. 2007) among children of differing social classes.

Although these and other material factors undoubtedly play roles in the origins of health disparities (Hackman et al. 2010), another prominent and increasingly persuasive explanation for such disparities is the SES-stratified differences in early exposures to family adversities and stressors (Brown et al. 2009; Hillis et al. 2004; Wadsworth et al. 2008). Low-SES children live with significantly more family chaos (Evans et al. 2005), sustain more frequent and severe psychological stressors (Evans 2004; Evans and Kim 


\section{Percent poor \\ adjustment}

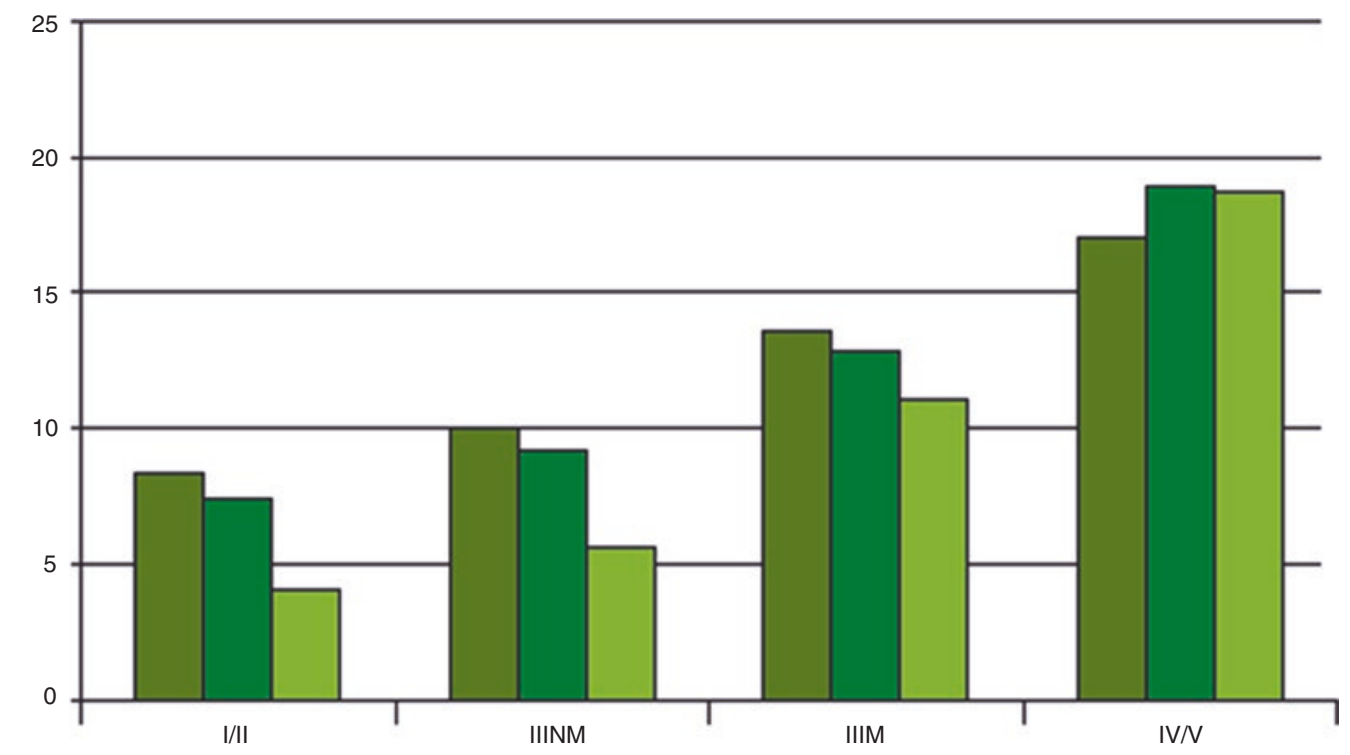

Aged 7

Social class at birth

$\square$ Aged 11

$\square$ Aged 16

Source: 1958 National Child Development Study ${ }^{64}$

Fig. 2 Rates of poor social/emotional adjustment at ages 7, 11, and 17, by father's social class at birth (Marmot 2010)

2007), and experience fewer supportive parentchild communications (Hart and Risley 1995), relative to their higher SES peers. Low SES children also show greater neurobiological sensitivity to aversive social contexts, in the form of heightened reactivity within the stress-responsive, neuroendocrine pathways, i.e., the hypothalamicpituitary-adrenocortical (HPA) axis and the autonomic nervous system (ANS) (Boyce et al. 2010; Evans and Kim 2007; Lupien et al. 2001; Steptoe et al. 2002). Further, the exaggerated reactivity of these peripheral stress response systems among disadvantaged youth is subserved by socially partitioned differences in central neural circuits, which also have profound influences on health development, cognitive function, and educational attainment (Curley et al. 2011; Cushing and Kramer 2005; Gianaros and Manuck 2010; Hackman and Farah 2009; MacDonald and Roskams 2009; McEwen and Gianaros 2010).

Influences of childhood SES on health and neurobiological endpoints extend beyond concur- rent effects on health and responsivity during childhood to longer-term relations with health status in adult life. Adverse experiences in early childhood, for example, may carry risk effects for coronary artery disease in adult life before the age of 50 years and effects mediated by some form of biological embedding (Kittleson et al. 2006). One important set of candidate mechanisms for such temporally distant effects is the constellation of pro-inflammatory changes that have been shown associated with childhood disadvantage. Programs of work by Miller and Chen (Miller et al. 2009a; Miller et al. 2009b), Cole (Cole 2009; Cole et al. 2007) and others (Danese et al. 2008; McDade 2012), for example, have demonstrated systematic differences in cytokine signaling pathways, transcriptional control, and risk for inflammationand immune-mediated disease. These studies suggest that changes in immune responsivity and the molecular processes involved in inflammation may be one category of mediating events linking childhood social adversity to adult disease. 


\section{(a) Males}

\section{Percent}

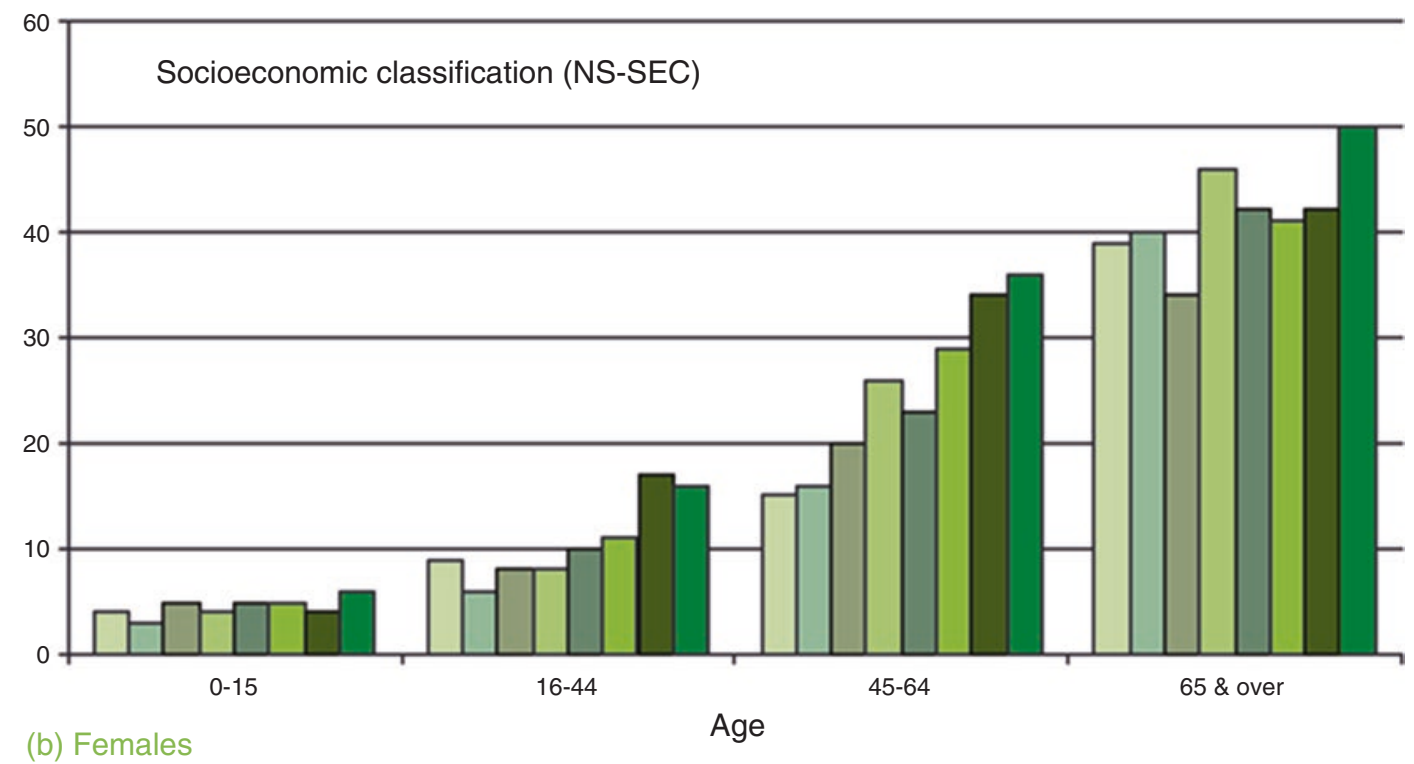

\section{Percent}

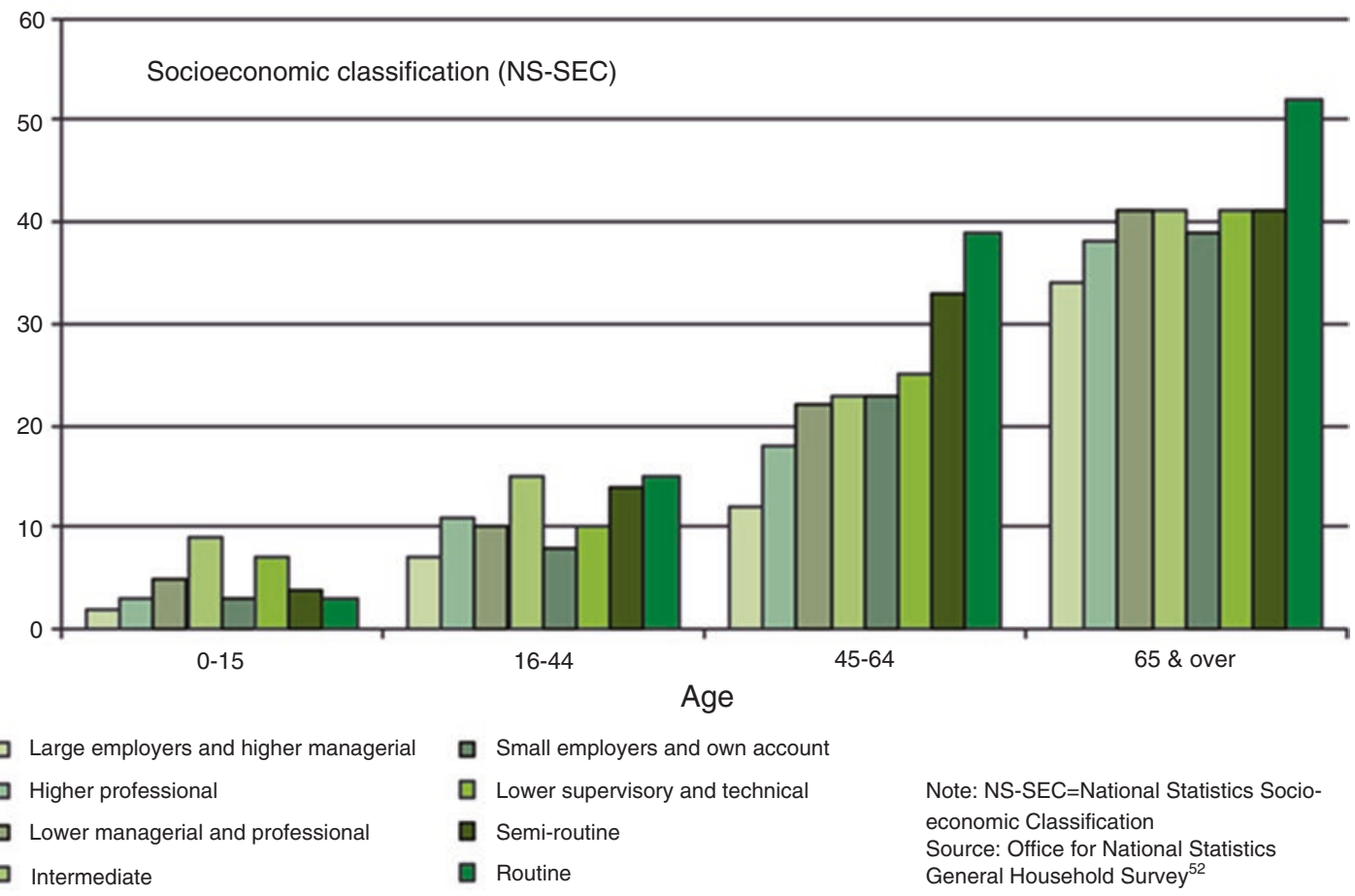

Fig. 3 Percentage of males and females with limiting long-term illness, by age and socioeconomic classification (Marmot 2010) 
Finally, there is emerging evidence that experiences of social subordination per se, themselves prevalent sources of human adversity (Keltner et al. 2003), may be related to disorders of mental and physical health, educational failure, and maladaptive behavior, especially in the young. The works of Pellegrini (Pellegrini et al. 2007, 2010), Hawley (Hawley 1999), and Fehr (Fehr et al. 2008) and their colleagues, describing the developmental emergence, behavioral signs, and socioemotional sequelae of childhood dominance and egalitarianism, have offered important "down payments" on such a research agenda. More recently, we have examined linkages between subordination and maladaptive health outcomes in a socioeconomically and ethnically diverse sample of kindergarten children, assessing associations between experiences of dominancesubordination and patterns of maladaptive behavior (Boyce et al. 2012a). As shown in Fig. 4, we found that indicators of mental health in 5-year-old children were stratified within classroom hierarchies in a manner parallel to that seen in larger, adult societies. Children occupying subordinate positions within their classrooms had more depressive symptoms, more frequent episodes of inattention, fewer positive peer relationships, and less evidence of prosocial behavior. Further, we found that the children most likely to show low or diminishing health status were those occupying subordinate social positions who also came from low SES families, and those least likely to show a diminution in health came from classrooms with teachers highly invested in learner-centered pedagogical practices (LCPs). Indeed, as shown in Fig. 4, the link between rank and behavior nearly disappeared in classrooms with strong teacher LCPs, suggesting that classrooms with egalitarian, student-centered "cultures" produced diminished mental health effects of hierarchical social ranks.

Such findings - that social subordination is associated with decrements in mental health, even within hierarchical, early childhood groups - are commensurate, moreover, with prior findings that subjective estimates of social class may be a stronger predictor of health outcomes than objective indicators, such as job status, income, or wealth (Adler et al. 2000; Goodman et al. 2003; Ostrove et al. 2000), and that dominance status in primate social hierarchies is similarly associated with health, even among captive animals with equal access to food, open environments, and veterinary care (Abbott et al. 2003; Cohen et al. 1997; Kaplan et al. 1982; Sapolsky 2005).

A growing body of research thus demonstrates powerful, graded effects of childhood social stratification and SES on development and health, both in children and their adult counter-
Fig. 4 Depression by social position and learner-centered pedagogical practices (LCPs) at half-SD increments from the mean $(-1,-0.5$, mean, $+0.5,+1 \mathrm{SD}$ ) (Boyce et al. 2012a)

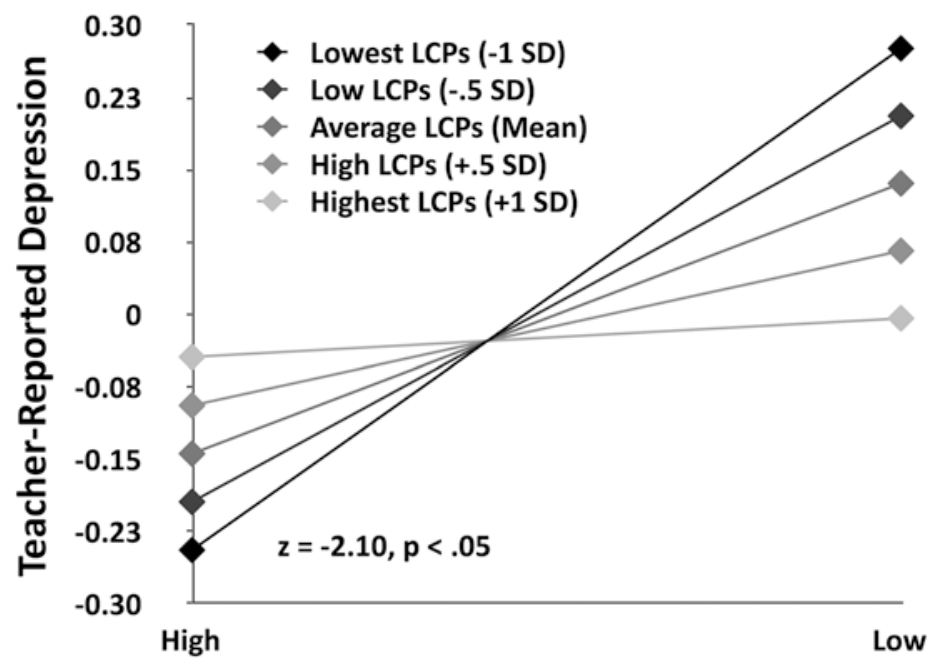

Social Position 
parts. Such effects may account, at least in part, for the strikingly uneven distribution of morbidities within human populations. Nonetheless, as noted by Kessler, Duncan, and colleagues (e.g., Kessler et al. 2014), results of large-scale human experiments challenge assumptions that simply augmenting financial resources or moving children out of high-poverty neighborhoods will have salutary effects on health development. Childhood SES effects are likely mediated by a broad array of factors that include diet, exposures to toxic environmental agents, differences in parenting, and access to health care, but substantial evidence also now implicates differential exposures to stress and adversity as a major mechanism of SES influence. Acquired differences in neurobiological reactivity to stressors and pro-inflammatory shifts in immune signaling pathways may also play an important mediating role in SES-health relations. Lastly, research has also begun to document effects of social subordination per se on childhood health outcomes, independent of family or neighborhood SES. Thus, relations between social position within classroom peer hierarchies and subsequent health outcomes show the same graded associations with morbidity found in studies of nations and large human populations.

\subsection{Vulnerability, Resilience, and Neurobiological Susceptibility}

The aggregation of ill health within human populations appears also attributable to constitutional differences underlying a remarkable variation in susceptibility to social-environmental influence. There is now growing evidence for a generalized sensitivity to social contexts within a human subgroups, i.e., highly sensitive or environmentally "permeable" individuals showing maladaptive outcomes in conditions of adversity but unusually positive outcomes in settings characterized by support, predictability, and protection (see, e.g., Aron et al. 2012; Belsky et al. 2007; Boyce 2016; Boyce and Ellis 2005; Ellis et al. 2011a).
Such individuals thus show either the least or most adaptive outcomes within the population, depending upon the character of the proximal social contexts in which they are reared. Studies demonstrating this greater susceptibility of neurobiologically responsive children to both positive and negative aspects of their environments have implicated a wide variety of:

- Stressors and adversities, including paternal depression (Cummings et al. 2007), marital conflict (El-Sheikh 2005; El-Sheikh et al. 2007), parental psychopathology (Shannon et al. 2007), and overall family distress (Obradovic et al. 2010)

- Positive environmental features, including parental warmth (Ellis et al. 1999), beneficial experiences and exposures (Pluess and Belsky 2013), and supportive interventions (BakermansKranenburg et al. 2008a)

- Defining biological parameters, including physiological reactivity (e.g., Alkon et al. 2006; Boyce et al. 1995), differences in brain circuitry (Whittle et al. 2010), and gene polymorphisms (Bakermans-Kranenburg et al. 2008b; Knafo et al. 2011; Manuck et al. 2011)

Most importantly, highly susceptible children (and adults) show bidirectional effects on outcomes in contrasting highly supportive and highly stressful settings - not simply an attenuation of negative effects in low stress circumstances.

Such differences in neurobiological sensitivity-likely based, in part, on genetic and epigenetic variation (Boyce and Kobor 2015) are figuring prominently in the field's exploration of the biological embedding of early stress. Findings suggesting differential susceptibility have been replicated in many samples of children, a troop of rhesus macaques (Boyce et al. 1998), and in a series of randomized controlled trials of socially supportive interventions (Bakermans-Kranenburg and Van Ijzendoorn 2015; Quas et al. 2004). Neurobiological sensitivity has also been the focus of a ten-paper special section of Development and Psychopathology 
Fig. 5 Incidence of violent injuries in free ranging macaques by confinement stress and reactivity status (Boyce et al. 1998)

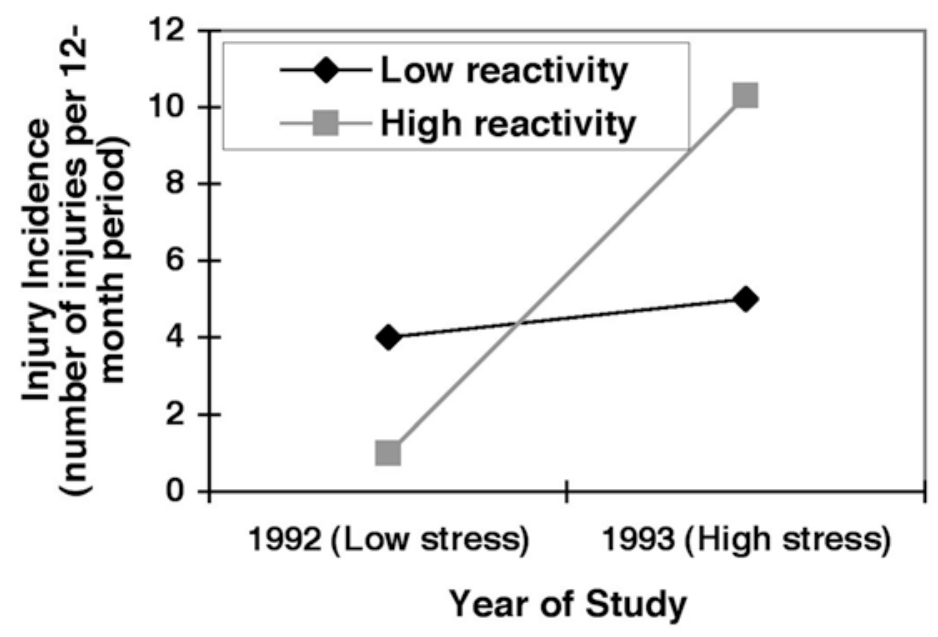

Importantly, strong evolutionary arguments have been made, albeit not without dissension (e.g., Bateson and Gluckman 2011; Overton and Lerner 2014; West-Eberhard 2003) for the conservation of environmental sensitivity within rearing environments of evolutionary adaptedness. Slavich and Cole, for example, have summarized recent evidence on how social-environmental exposures can regulate gene expression, thereby calibrating individual sensitivity to social context (Slavich and Cole 2013). Such sensitivity appears to influence not only the rates and severity of morbidity but also the timing and pace of important developmental transitions, such as puberty (Ellis et al. 2011b). This characteristic, which probably becomes increasingly trait-like over the course of development, appears to emerge as a conditional adaptation, garnering signals from the early social environment about the inherent levels of threat, adversity, support, and nurturance that the growing child is likely to encounter and calibrating stress-responsive biological systems to optimize survival, health, and developmental well-being (Ellis et al. 2006, 2011a; Hane and Fox 2006). Understanding phenotypic variation in environmental susceptibility might logically also play a role in the conceptualization and development of newly individualized approaches to "precision medicine" (Committee on a Framework for Development a New Taxonomy of Disease 2011). parts) in positive, low stress settings. 


\subsection{The Topography of Vulnerability}

In addition to their aggregation within population subgroups, developmental vulnerability and ill health are also clustered by spatial geography. It is well known, for example, that of the more than 7 million of the world's children less than 5 years of age that die each year, the majority live in the regions of sub-Saharan Africa and South Asia (Liu et al. 2012). Equally familiar is the epidemiologic, small area clustering of neurodevelopmental disorders such as autism spectrum disorder (Mazumdar et al. 2010). Less well known, but equally compelling, are the dramatic differences in developmental vulnerability at primary school entry-differences with major implications for learning and academic success - that are found within major national jurisdictions, such as the Canadian province of British Columbia (see Fig. 7).

Between 2000 and 2011, the provincial BC government, with the assistance and oversight of the Human Early Learning Partnership at UBC Vancouver, completed four population-based assessments of developmental health. Assessments were completed during the kindergarten year, and developmental health was measured using the Early Development Instrument (EDI), a kindergarten teacher-completed checklist for each child based on five scaled measures of development: physical well-being, social competence, emotional maturity, language and cognitive development, and communication and general knowledge (Janus and Offord 2000). The EDI yields, for each child and each scale, a score as "vulnerable" or "not vulnerable." The designation as "vulnerable" is not given directly to the family, however; rather, rates of EDI vulnerability are computed and mapped according to residential neighborhoods where children live. Mapping is done by neighborhoods because local geography defines unique combinations of factors that support or undermine early child development.

Across Canadian neighborhoods, vulnerability rates on one or more of the EDI scales range from

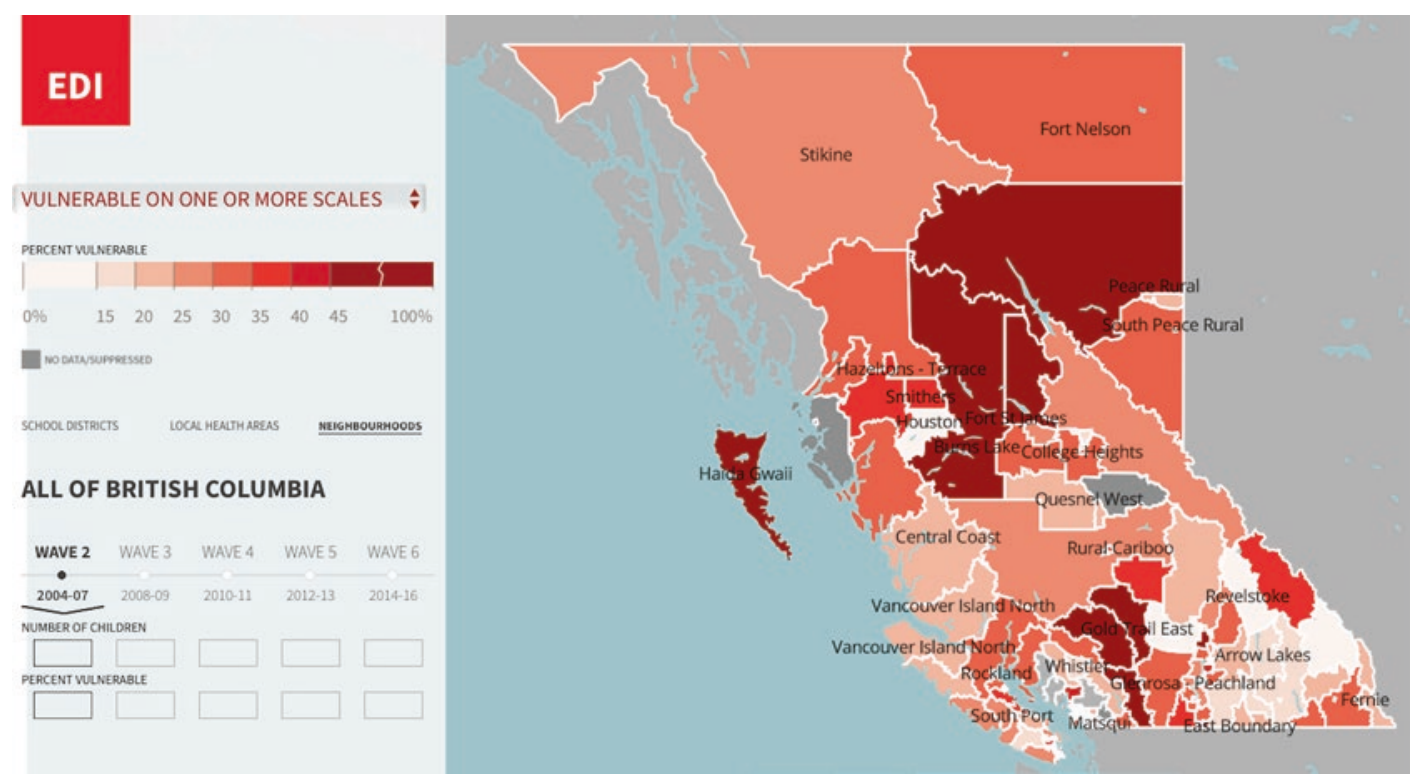

Fig. 7 Neighborhood variation in developmental vulnerability in British Columbia on the early development instrument (http://earlylearning.ubc.ca/interactive-map/) 
as low as $4 \%$ to as high as $69 \%$, such that there is a more than 17-fold inequality in developmental vulnerability in Canada at the level of the neighborhood. This range is much larger than would be predicted on the basis of random sample surveys of child development, which rarely demonstrate social gradients larger than threefold. Neighborhoods aggregate family environments, reflect broader environments, and have emergent properties, such as safety and social cohesion, that influence developing children. They tend to include families of similar socioeconomic status, unique mixes of relational characteristics (i.e., the factors that shape a family's social identity), and similar levels of access or barriers to programs and services. For analytical purposes, random sample surveys aggregate children from different geographical locales into statistical (rather than real) neighborhoods according to a small number of grouping factors (e.g., median family income or proportion of adults with high school graduation). Such "neighborhood effect" analyses from random sample surveys do not capture the unique circumstances of real neighborhoods. Thus, the 17-fold variation in EDI-estimated developmental health validates this spatial geographic approach to local differences, since only this tactic captures the circumstances of real neighborhoods (Hertzman 2010; Kershaw et al. 2009). Such an approach has been used, for example, to reveal that optimal, area level EDI scores occur within neighborhoods with mixed, rather than uniformly affluent, SES representation, i.e., those with relatively equal proportions of affluent and disadvantaged families (Carpiano et al. 2009). Adopted on an even larger scale, such methods are capable of offering social ecological perspectives on the physical, socioeconomic, and social political conditions of children on a global scale (Panter-Brick et al. 2012).

\subsection{Marginalization and Scapegoating}

Interpersonal marginalization and scapegoating can also contribute to uneven distributions of morbidity and maladaptive development, often based on targeting by individual, constitutional characteristics.
Victimization is a well-represented and elemental human behavior, even within groups of very young children. Described by Lord Byron as "the longest pleasure" (Don Juan, 13th Canto: "Now hatred is by far the longest pleasure; Men love in haste but they detest at leisure."), hatred and stigmatization have remained, for all of history, a sadly defining feature of human societies. Family systems theory has regarded scapegoating and the designation of an "identified patient" as an effective if personally costly means of securing family solidarity (Vogel and Bell 1961), much as the vilification of Simon in William Golding's Lord of the Flies served the cohesion of a marooned band of lost school boys. Behavioral vulnerability stemming from physical weakness, anxiety, poor social skills, or chronic illness has been shown to engender victimization in groups of children (Egan and Perry 1998; Sentenac et al. 2012), and within nonhuman primate troops, the active targeting of highly reactive, more sensitive members has been described during periods of intensive group stress (Boyce et al. 1998). Far from restricted to Western, individualist societies, bullying and victimization are also highly prevalent in more collectivist cultures (Kim et al. 2004). Among human children and youth, such victimization can undermine mental health and lead to poor academic performance (Glew et al. 2005), psychosomatic disorders (Arseneault et al. 2006; Gini and Pozzoli 2009), suicidal ideation behavior (Kim et al. 2009; Turner et al. 2012), and later criminality (Sourander et al. 2007). Among the survivors of populationlevel genocide, specific genetic variants have been linked to traumatic memory retention and the level of risk for post-traumatic stress disorder (PTSD) (de Quervain et al. 2012). Abusive experiences in children, whether at the hands of family or peers, become itself a social determinant of adult mental and physical health (Greenfield 2010), resulting in the sequestering of morbidities within both perpetrators and their victims.

\subsection{History and Affliction}

As Kuzawa and Thayer noted (Kuzawa and Thayer 2011), human adaptation to environmental conditions takes place at a variety of timescales, ranging from homeostatic changes that can 
occur over seconds or minutes to developmental plasticity emerging over months or years to conserved genetic changes that operate on a timescale of millennia. Thus, historical contexts can also concentrate and skew distributions of disease and disorder over epochs of time. For example, prenatal exposures to a natural disaster, such as the 1998 Québec Ice Storm, can contribute to the risk for childhood obesity, even after adjustment for breastfeeding, SES, obstetrical complications, and smoking during pregnancy (Dancause et al. 2012). During historical periods of war, elevated lifetime risks for PTSD are found among children exposed to violent or traumatic events (Javidi and Yadollahie 2012). Researchers have also studied how early life exposures to famine can influence adult health, using historical cohort data from the Finnish crop failure famine of 1866-1868, the Dutch Hunger Winter of 1944-1945, the Siege of Leningrad in 1944, the seasonal famines in the Gambia between 1949 and 1994, and the Chinese Great Leap Forward famine of 1959-1961. Outcomes examined have included adult height and weight, glucose metabolism, blood pressure, lipid profiles, metabolic syndrome, cardiovascular outcomes, self-reported health, mental performance and cognition, mental disorders, and adult mortality (Falconi et al. 2017; Lumey et al. 2011). Exposure episodes related to war, such as the 1944-1945 Dutch Famine of World War II, resulted in elevated odds of developing coronary heart disease in adult life (Painter et al. 2005; Roseboom et al. 2000) and in systematic differences in the epigenetic modification of genes such as insulin-like growth factor (IGF-2) (Heijmans et al. 2008) and aspects of risk that appear capable of crossing into unexposed generations (Painter et al. 2008). Genocide, whether historical in the case of the Holocaust or contemporary, as in the Rwandan atrocities, exerts powerful, lasting damage on children's prospects for health and wellbeing, both contemporaneous and longitudinal (Hazani and Shasha 2008; Oberg 2008). Each of these examples illustrates how time, in the form of historical period, and context, in the form of broad socioenvironmental perturbations and assaults, converge to influence and bias life course health development.

\subsection{Critical Periodicity}

Finally, events and exposures within developmental time, rather than historical time, also create constraints and opportunities for healthy development and the avoidance of disorder. The function of neuronal circuits in the brain is guided by experiences in postnatal life that regulate the maturation of inhibitory connections and interneurons (Hensch 2005). Critical periods exist, for example, for the acquisition of language and discrimination of speech sounds in human infants (Weikum et al. 2012), and exposure to music can change auditory preferences in young mice through changes in prelimbic and infralimbic medial prefrontal cortex during an early critical period (Yang et al. 2012). Adult brain plasticity appears to become restricted by structural and functional developmental "brakes," such as perineuronal nets and myelin that inhibit neurite growth and the balance between excitatory and inhibitory circuitries (Bavelier et al. 2010). Genetic, pharmacological, and environmental influences can alter such plasticity, suggesting future opportunities for reopening closed critical periods, such as those for language acquisition or vision, or enhancing recovery from traumatic or cerebrovascular brain injury.

\section{Interactions Between Context and Constitution: The Biological Embedding of Early Adversity}

These arenas of research, defining the contextual and constitutional origins of disease maldistribution by population, space, and time, converge in a new and growing body of work examining the interplay between genes and environments in determining developmental and health endpoints over the life course. Such research comprises studies of (a) true gene-environment interactions, in which allelic variation moderates primary associations between environmental factors and outcomes, and (b) epigenetic processes, in which exposure-related chemical/structural 
modifications of chromatin up- or downregulate the transcriptional expression of functionally salient genes. Together, such studies and larger territories of research have begun to advance serious answers, at a variety of analytic levels, to the questions surrounding how socially partitioned early experience "gets under the skin," affecting broad life course trajectories of development and health (Evans et al. 2012; Hertzman and Boyce 2010; Slavich and Cole 2013).

\subsection{Chromatin Modification and the Molecular Biology of Epigenesis}

As shown in Fig. 8, chromatin is the structural packaging of DNA and its associated proteins into nucleosomes: strands of DNA wrapped around histone protein octamers, like thread around a spool. Nucleosomes in turn form a loosely or tightly wound chromatin "necklace," arrayed like beads on a string. Epigenetics has been defined as a functional modification of DNA that does not involve an alteration of sequence (Meaney 2010). The differentiation of embryonic stem cells into specific tissue lineages, for example, is epigenetically guided by patterns of downregulation and activation of lineage-specific genes (Wu and Sun 2006). Figure 9 shows how DNA methylation changes with development throughout the sequential ontogeny of germ cell development, fertilization, and embryogenesis. The more general processes of gene-environment interplay involve important functional distinctions between gene sequence, epigenetic modifications, and gene expression - variations in each of which may influence individual responses to environmental exposures. Gene sequence variation, for example, has been linked to vulnerability to a variety of maladaptive or disordered health outcomes (Caspi et al. 2002, 2003).

Differences in gene expression have also been associated with disease susceptibility (Liew et al. 2006; Mohr and Liew 2007) and are, in turn, related to a variety of epigenetic, molecular processes, which include DNA methylation, histone modification, production of noncoding microRNAs, presence of various transcription factors, and nucleosome remodeling (Gilbert and Epel 2009). Given the complexities of these chemical mechanisms, however, it is important to understand that (a) DNA methylation is only one form of epigenetic mark, (b) DNA methylation is not the equivalent of gene expression, and (c) it is sometimes unclear whether DNA methylation is a precursor of gene silencing or a marker of such silencing. For purposes of simplicity, the discussion here
Fig. 8 Chromatin and nucleosome structure (Courtesy of Joseph Roland(C) 2003 - www. cytographica.com)

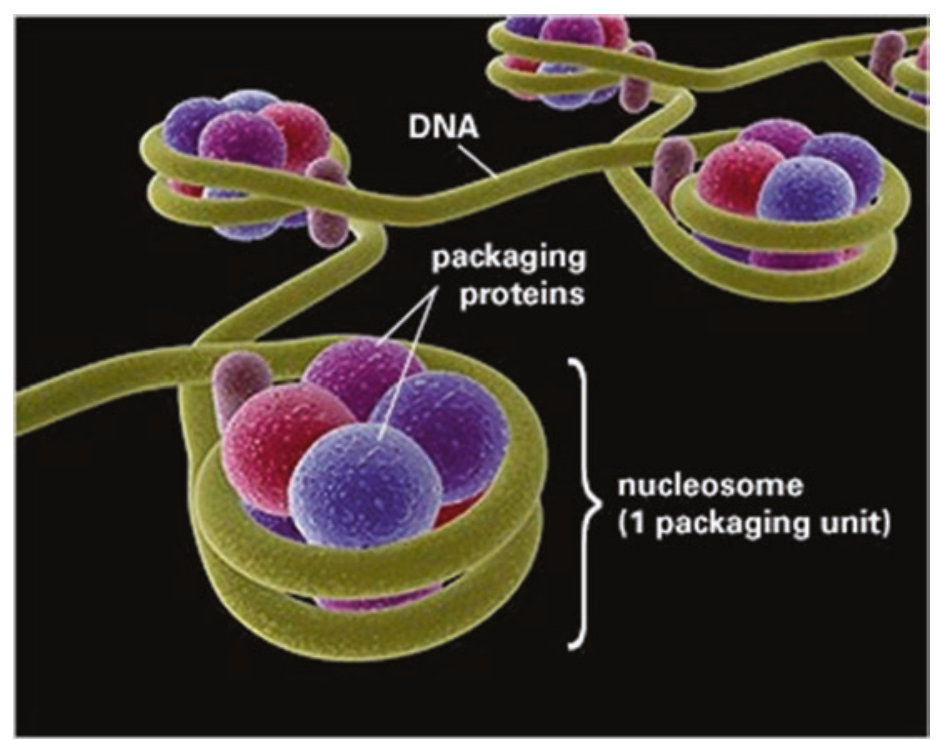




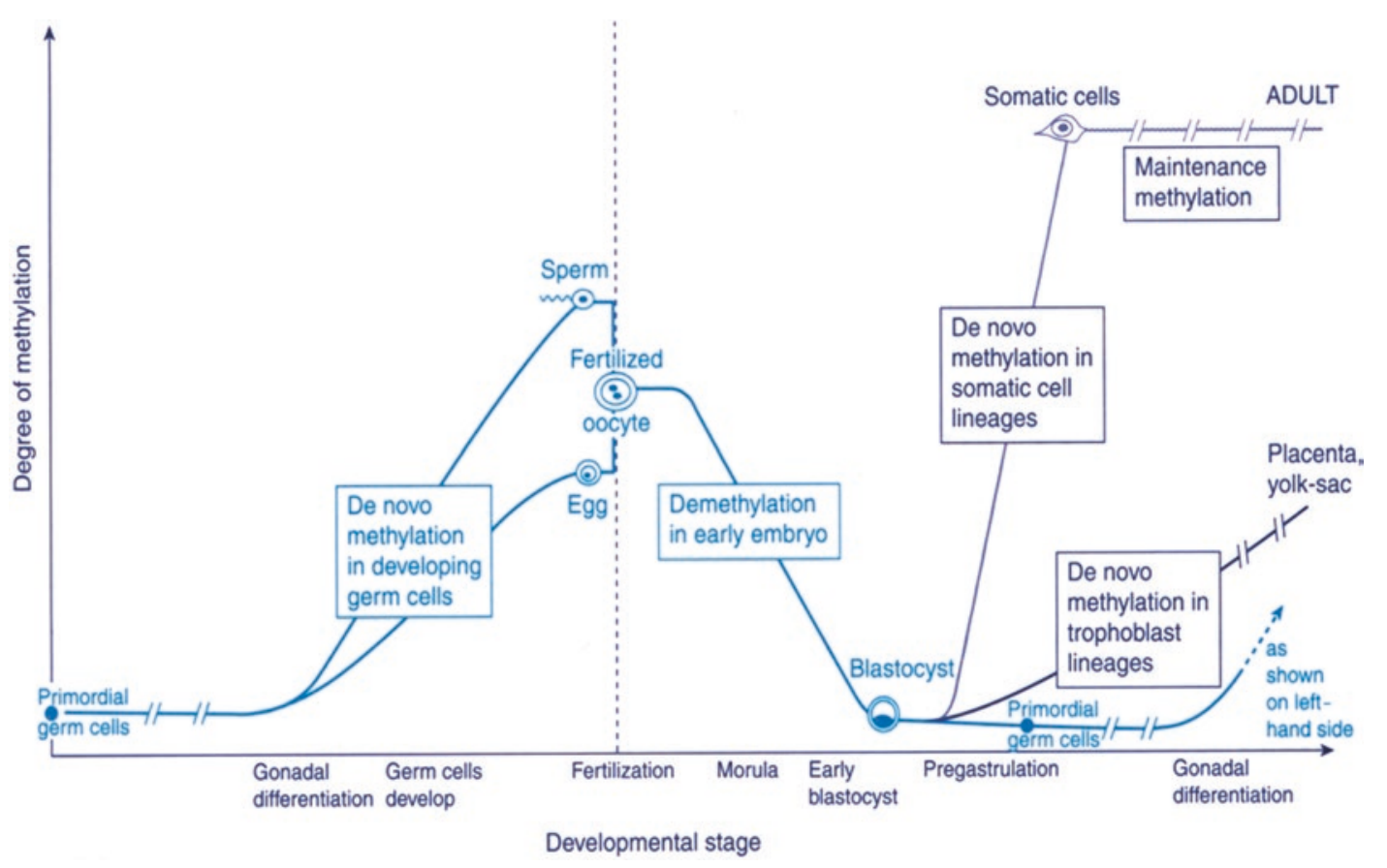

Fig.9 Epigenetic methylation events in early human gestation (Russo et al. 1999)

focuses primarily upon true gene-environment interactions and a single form of epigenetic modification, the methylation of cytosine-phosphateguanine $(\mathrm{CpG})$ dinucleotide sites in DNA. The relative stability of DNA methylation suggests that, among epigenetic marks, it may be responsible for longer-term, more developmentally important changes in gene expression.

As shown in Fig. 10, genes have both promoter and coding regions, with the latter demarcated by start and stop sequences recognized by RNA polymerase. RNA polymerase, in association with facilitating transcription factors (i.e., a "transcription complex"), transcribes the DNA coding region into messenger RNA, which in turn undergoes ribosomal translation into proteins that alter cellular function. Social experiences can result in epigenetic marks, such as CpG methylation, within a gene's promoter region, and the degree of such methylation regulates gene expression, like a dimmer switch regulates light in a room. Transcription start sites and promoters are known to be enriched with $\mathrm{CpG}$ sites (areas called "CpG islands") (Turner et al. 2008), and experience-induced methylation of these sites is known to tighten chromatin structure, rendering transcription factor binding sites physically less accessible and interfering with RNA polymerase attachment to the coding start sequence. Thus, the experience-induced methylation of a promoter $\mathrm{CpG}$ can effectively silence the gene, altering cellular function and changing physiological processes ranging from neurotransmitter reuptake in neuronal synapses to blood glucose regulation and sympathetic nervous system reactivity.

\subsection{The Epigenetics of Social Adversity}

Although the study of epigenetics began in the field of cancer biology, research has more recently begun to explore epigenetic processes by which socially stratified exposures to early adversities may condition long-term risks to development and health (Gluckman et al. 2007; Jirtle and Skinner 2007; Tsankova et al. 2007). There is evidence for DNA methylation-associated regulation of adversity-responsive genes in both 


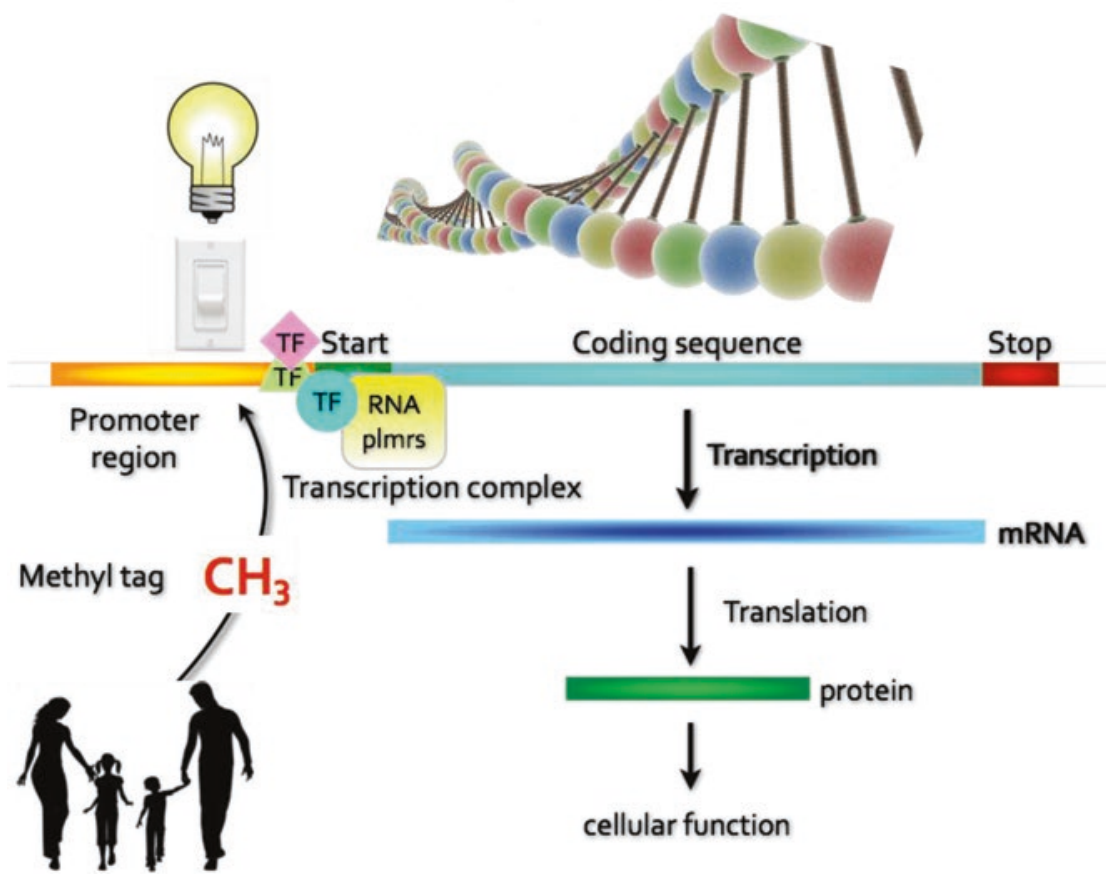

Fig. 10 Simplified representation of epigenetic modification and transcription regulation. $\mathrm{CH}_{3}$ methyl group, Tag TF transcription factor, RNA plmrs RNA polymerase, $m R N A$ messenger RNA

laboratory animals (McGowan et al. 2008) and human infants (Oberlander et al. 2008) and for stressor-associated differences in mRNA expression in human subjects (Cole et al. 2007; Morita et al. 2005). Further, the biochemical "markings" of genomic DNA and its associated, nucleosomal histone proteins are the epigenetic mechanisms by which the expression of neuroregulatory genes is controlled (Isles and Wilkinson 2008; Meaney and Ferguson-Smith 2010; Mehler 2008). Epigenetic marks are capable, through this governing of neuroregulatory gene expression, of guiding both neurodevelopment and the function of peripheral and central neural pathways (Liu et al. 2008; MacDonald and Roskams 2009).

The work of Meaney, Szyf, and colleagues (Szyf et al. 2008; Weaver 2009; Weaver et al. 2004; Zhang and Meaney 2010), for example, has demonstrated in the rat pup how maternal licking and grooming in the first several days of life downregulate pups' long-term HPA reactivity through increases in hippocampal glucocorticoid receptor (GR, NR3Cl) expression and serotonergic tone. Licking and grooming triggers increases in serotonin in the hippocampus, and activation of the 5-HT receptor induces expression of a transcription factor, nerve growth factorinducible protein-A (NGFI-A). Licking and grooming also facilitates NGFI-A's association with the exon $1_{7}$ GR gene promoter by demethylating a CpG site located in the NGFI-A binding region of this exon. The resulting increased expression of GR results in a downregulation of corticotropin-releasing hormone (CRH) and diminished activation of the HPA axis. Readers are referred to (Hackman et al. 2010) for more detailed description of these molecular events. Other work in rat models of early infant maltreatment has demonstrated enduring methylation of the gene coding for brain-derived neurotrophic factor (BDNF), reduced BDNF expression, and extension of both epigenetic marks and maltreatment of young into a subsequent generation (Roth et al. 2009). Because BDNF is a key mediator of neural plasticity in brain regions such as the prefrontal cortex and hippocampus, such findings might present a legitimate model of the neurocognitive sequelae of transgenerational 
neglect and abuse of human children. Champagne and colleagues (Champagne et al. 2006) have also shown, in the same model, that the increased estrogen receptor- $\alpha$ (ER- $\alpha)$ expression that occurs in the medial preoptic area of high licking and grooming mothers is associated with cytosine methylation of the ER- $\alpha$ gene promoter.

Nonhuman primate work by Kinnally et al. (Kinnally et al. 2010a, 2010b, 2011) has explored, in infant macaques, interrelations among early stressors (social group vs. nursery rearing and variable foraging vs. control conditions), allelic variation in the 5-HTT serotonin transporter gene promoter, and both genome-wide and 5-HTTspecific differential methylation in peripheral blood mononuclear cells (PBMCs). Among their findings with direct relevance to the research considered here are the following:

- Higher 5-HTT CpG methylation, but not sequence variation in the serotonin transporter promoter region, exacerbates the effects of early life stress on behavioral stress reactivity.

- Both greater 5-HTT and whole-genome methylation level (i.e., 5-methylcytosine content) is associated with enhanced stress reactivity across the subsequent life span.

- When brain tissue is unavailable for methylation analysis, peripheral blood methylation levels may serve as useful surrogates (see also Cupello et al. 2009; Uebelhack et al. 2006).

The Meaney-Szyf research group has also recently advanced evidence, in the postmortem hippocampi of human suicide victims, for hypermethylation of the ribosomal RNA gene and $N R 3 C 1$ gene promoters and epigenetic marks suggesting dysregulation in cellular protein synthesis machinery and HPA responsivity (McGowan et al. 2008, 2009). Further, two prospective human studies have now documented differential patterns of DNA methylation conditional upon various aspects of early childhood adversity. First, genome-wide, blood DNA methylation analysis in low- and high-SES subjects from the 1958 British Birth Cohort revealed a cluster of probes obtained from the 500 most variable promoters that was enriched with highSES individuals, confirming that SES differences contributed to overall epigenetic variation. Methylation levels for 1,252 gene promoters were associated with childhood SES versus 545 promoters for adulthood SES (Borghol et al. 2012). Second, in a subsample of adolescents from the Wisconsin Study of Family and Work birth cohort, Essex et al. (Essex et al. 2013) found differential methylation in $170 \mathrm{CpG}$ sites among participants whose parents reported high levels of stress during their children's early lives. Maternal stressors in infancy and paternal stressors in the preschool years were most strongly predictive of differential methylation, and the patterning of such epigenetic marks varied by children's gender. Both birth cohort studies suggest that epigenetic signatures detectable in adolescence to mid-life are related to early experiences with stressful environments. Other human research has documented:

- Altered DNA methylation of the insulin-like growth factor gene (IGF2) in individuals exposed prenatally to the Dutch Famine of 1944-1945 (Heijmans et al. 2008)

- Increased NR3C1 methylation at an NGFI-A binding site in newborns exposed to mothers' depressed mood in the third trimester of pregnancy (Oberlander et al. 2008)

- Highly variable methylation patterns within the five GR promoters activated in PBMCs, possibly reflecting epigenetic fine-tuning of GR expression by early life experiences (Turner et al. 2008)

- Pro-inflammatory shifts in cytokine expression among young adults with low-SES childhood histories, via transcriptional signaling changes in adrenergic and adrenocortical pathways (Chen et al. 2011; Miller et al. 2009a)

- Both between-tissue and between-individual discordance in epigenetic marks at the insulinlike growth factor, IGF2/H19, locus in multiple tissues at birth, even among monozygotic twins (Ollikainen et al. 2010)

- Differences in risk for psychopathology related to concurrent allelic and epigenetic 
variation, such that trauma-related 5-HTT promoter methylation operates as a moderator of the association between the 5-HTT polymorphism and psychological problems (van IJzendoorn et al. 2010)

Taken together, these observations offer evidence for social-environmental regulation of mammalian and human gene expression, at the levels of both whole-genome and candidate gene methylation (Cole 2009). The findings also suggest that divergences in methylation and gene expression begin early in development, even during intrauterine life, and that socially partitioned stress and adversity may be transmuted into mental health risks through molecular modifications of the epigenome. Differential exposures to environmental events may explain, for example, the diverging trajectories of epigenetic profiles found among monozygotic twins over time (Fraga et al. 2005). More broadly, epigenetic remodeling in response to developmentally potent environmental events may serve as a mechanism for neural plasticity and the conditional production of individual differences in attributes and risks for psychopathology (Bagot and Meaney 2010).

\subsection{Gene-Environment Interplay in Brain Development}

Indeed, there is already emerging evidence that brain processes and neural plasticity may function as key mediators in the linkages between G-E interplay and developmental and health endpoints. Bush et al., for example, have recently shown that the BDNF Val66Met polymorphism confers an increased neuroendocrine sensitivity to socioeconomic context, with Met carriers having the highest and lowest cortisol expression levels, depending on SES (N. Bush, personal communication, unpublished data, 2017). Other findings in the nascent science of "imaging genomics"-a field merging high-throughput genotyping with new brain imaging technologies - are revealing how variations in DNA sequence are associated with structural and functional connectivity in specific brain regions
(Thompson et al. 2010). Recent fMRI studies, for example, have demonstrated the heritability of patterns of task-related brain region activation and shown how the COMT val108/158met functional polymorphism is associated with systematic differences in prefrontal cortical physiology and function (Egan et al. 2001). Consistent with the same general hypothesis, Hariri and colleagues (Hariri et al. 2005; Hariri and Weinberger 2003) have found that subjects carrying the less efficient short allele of the 5-HTT gene promoter had an increased amygdalar response to fearful stimuli in comparison with subjects homozygous for the long allele. Even more to the point in regard to the development of brain structures subserving socioemotional development, Alexander et al. (Alexander et al. 2012) recently reported a significant GxE interaction effect on neural response patterns and functional amygdalahypothalamus connectivity-circuitry that appears closely tied to emotional control and the interpretation of social processes (Blakemore 2010; Norman et al. 2012). Such findings begin to reveal possible neural substrates for previously observed, epidemiological observations linking functional polymorphisms, early stressful events, and vulnerability to psychopathology (Caspi et al. 2003; Moffitt et al. 2005).

Also coming into view through the work of a range of investigators (Adolphs 2009; Blakemore 2010, 2012; Lesch 2007; Norman et al. 2012; Robinson et al. 2005, 2008) is a new corpus of research describing and exploring the social brain. Such work has begun to address a neurogenomic basis for complex social cognitions, including the capacities for inferences about others' thoughts and emotions (a cognitive ability referred to in the child development literature as "theory of mind"), recognition of self, processing of facial information, differentiation of social opportunities and challenges, and control of socially evoked emotion. The substrates for these capacities are already known to lie, at the neural circuit level, in functional connectivity between limbic structures, such as the amygdala, hippocampus, and basal ganglia, and prefrontal cortical regions, including the dorsolateral and orbitofrontal cortex, the anterior cingulate and 
the posterior superior temporal sulcus at the temporoparietal junction. At the molecular level, there is evidence for perturbations in the functionality of such circuits related to allelic and epigenetic variation in genes such as those coding for the serotonin transporter (Lesch 2007), oxytocin (Norman et al. 2012), and endorphins (Keverne et al. 1989). There is to date no single definition of the social brain, but a consensus appears to be forming that a subset of autonomic, neuroendocrine, neural, and genomic processes influence and are influenced by aspects of social cognition and behavior (see Robinson et al. 2005, 2008). Although it will be important to avoid a simplistic attribution of complex cognitive and perceptual events to discrete neural, endocrine, or cellular structures (Norman et al. 2012), there is clearly much to be learned about the nature of sociality, the mechanisms that underpin it, the degree to which these mechanisms are conserved in animal phylogeny, and the implications of perturbations in its development.

In sum, a burgeoning research enterprise is producing evidence, in both animal models and human studies, that many if not most human morbidities have their points of origin in early childhood (Shonkoff and Garner 2012), are the products of gene-environment interplay (Rutter 2006), and influence developing neural circuits that are directly linked to long-term trajectories of health, disease, and life achievement. Although the fields of social epigenetics and developmental neuroscience are yet in their relative infancies, promising advances in both suggest a scientific frontier in which functional interactions among social environments, genetic and epigenetic variation, and the functionality of neural circuits will offer compelling new knowledge of how developmental variation emerges.

\section{Summary: What We Know and What We Don't}

Deep cultural traditions affirming the special sensibilities of children and the echoing of childhood difficulties and stress into the decades of adult life are becoming now powerfully grounded in a new science describing the biological embedding of early social adversity (Boivin and Hertzman 2012; Boyce et al. 2012a; Hertzman and Boyce 2010). No longer relegated to categories of either unsupported belief or speculative hypothesis, the science of early child development has become a multidisciplinary landscape of novel findings documenting prospective, longitudinal associations, powerful and increasingly causal understandings of mechanism and mediation, and new levels of observation made possible by dramatic technological advances. Among the discrete, foundational discoveries that have become the products of this science are the following:

1. Epidemiologic and population-based studies have soundly documented the propensity for morbidities and difficulties of all kinds - biomedical diseases, psychiatric disorders, injuries, and academic, professional, and personal underachievement - to aggregate by population, space, and time, thereby disproportionately affecting small subgroups of individuals, during constrained periods of historical or developmental time. Thus, especially during periods of strife, war, or economic decline, those people whose health and well-being are most harshly and persistently vulnerable are likely to issue from impoverished, alienated, or otherwise marginalized groups. Misfortune is neither stochastically nor evenly distributed within human populations, and the inequalities that ensue from maldistribution are serious, ethical, and public health challenges to society's commitments to justice and health equity. Our societal aspirations to create a more "empathic civilization" (Rifkin 2009) will demand a more human practice of medicine (Halpern 2001), a broader allegiance to unbiased opportunity (Robert Wood Johnson Foundation Commission to Build a Healthier America 2009), and a deeper commitment to the rich pluripotentiality of young lives (Shonkoff and Phillips 2000).

2. Studies examining the developmental biology of social adversity have positioned this new 
science on the cusp of deep mechanistic explanations for the important, earlier insights of Waddington (Waddington 1959, 2012), Gottlieb (Gottlieb 1991), and others (Gilbert 2002; Karmiloff-Smith 2007; Meaney 2010) - insight that organismic development is guided by the combined, interactive influences of genes and experiences. We now know that development includes not only gene expression regulation through experiential modification of chromatin structure but also by real GxE interactions and the joint, interactive effects of allelic variation and chromatin modification together (see, e.g., Lam et al. 2012; Pezawas et al. 2005; Rutter 2012). As asserted here and elsewhere, the simple partitioning of developmental variance into genetic and environmentally determined components now falls far short of a truly interactive view of the operation of nature and nurture (Meaney 2010). Coming now steadily into view are the actual molecular mechanisms by which constitution and context conjointly determine differences in health and development, both in childhood and over the lifespan.

3. The origins, dimensions, and consequences of individual differences in phenotype are emerging as essential components in a full understanding of the biology of social adversity. Biology is replete with both between- and within-species variation that bears convincing witness to the evolutionary uses of diversity, and elegant ethological and epigenetic work, such as that by Meaney (Meaney 2010), Szyf (McGowan and Szyf 2010), and Suomi (Suomi 2006), reveals the adaptive benefits of phenotypic diversification. There is the nearly tautological reality that the operation of natural selection demands the genetic diversity achieved through spontaneous mutation, but beyond such self-evident principles, there are clear examples of how species diversification enhances survival and fitness. Thus, maternally and epigenetically regulated differentiation of rat pups' adrenocortical responsivity produces a range of low to high reactivity phenotypes, each of which may maximize survival and fitness within particular, early and later life environments (Weaver et al. 2004). Similarly, neither the aggressively uninhibited nor the shy, neophobic phenotypes of young rhesus macaques can be warranted as "normal" or optimal; rather, each has adaptive value within specific social and physical contexts (Cirulli et al. 2009; Stevens et al. 2009). What is salient and important about phenotypic variants is their capacity for enhancing fitness within the diversity of species-typical environments encountered. One illustrative variant are those children and young nonhuman primates that evince an exceptional neurobiological susceptibility to aspects of social settings, a phenotype likely representing a conditional adaptation to early environmental signals (Barr et al. 2004; Belsky 2005; Boyce and Ellis 2005; Ellis et al. 2011a). Such individuals show a heightened risk of morbidity under conditions of stress and adversity but exceptionally good health and positive development in settings characterized by support, nurturance, and stability.

4. Increasingly visible within the emerging literature on the neurobiological consequences of early life adversity is a new collection of studies and papers examining the social brain (Adolphs 2009; Blakemore 2010, 2012; Lesch 2007; Norman et al. 2012; Robinson et al. $2005,2008)$. The brain has evolved to acquire specific organizational circuits, cortical regions, and subcortical structures dedicated to the detection of survival threats, and social experiences of loneliness, abandonment, or neglect may chronically activate such circuitry, creating long-term perceptual and affective biases and fundamentally altering a child's view of the social world (Eisenberger and Cole 2012). Such circuitry is also represented in the periphery, with both animal (Insel 2010) and human (Norman et al. 2012) studies documenting effects on social affiliative processes mediated in part by hormonal events such as the expression of oxytocin and vasopressin.

5. As also discussed, a remarkable diversity of early, social environmental dimensions has been linked to important differences in mental 
and physical health, trajectories of development, and individual differences in behavior. Such dimensions include, but are not limited to, acute and chronic stressors, poverty and subjective social marginalization, and the absence of positive contextual factors, such as good parenting or a child-supportive community. Of apparently particular importance to social epidemiologic perspectives on early development are studies describing and documenting the effects of social hierarchies, structural subordination, bullying, discrimination, and victimization. The hierarchical and networked social structures found across phylogeny - literally from fruit flies (fish and primates) to human kindergartners (see Boyce et al. 2012a; Fernald and Maruska 2012; Schneider et al. 2012)-suggest an evolved predisposition with implications for survival, reproduction, and safety. Although such hierarchies may be a heritable legacy from our evolutionary past, promising new work addresses approaches to minimizing the health effects of subordinate social positions at the levels of societies, communities, and schools. Such work also attests to the individual and societal benefits of fostering the development of empathy, altruism, and sociality.

6. The central role of time-evolutionary, historical, developmental, neurogenomic, and neurophysiological-in determining phenotypic variation is another recurrent if often implicit theme in emerging developmental science. Much of the biological embedding of current social contexts reflects response predispositions established, selectively and epigenetically, through adaptations to the temporally distant environments of early hominids (Dubos 1965; Nesse and Young 2000). Social disparities in health-products, in part, of the social, economic, and health policies of contemporary societies - wax and wane within historical time according to the era's dominant sociopolitical philosophies (Beckfield and Krieger 2009; Krieger 2001). Further, developmental time is strikingly uneven in its potency, intensity of change, and accessibility to environmental influence.
Thus, at quite different levels of temporal resolution, time and timing appear to play crucial, but not yet fully explored, roles in guiding societal, organismic, and neurobiological responses to the conditions of early life.

Taken together, these points of emerging empirical evidence form a constellation of discoveries defining a new and lively research field and the social and developmental biology of early adversity and its influences on life course development and health. Although substantial recent progress has been made within a broad assortment of disciplines, much new research, conceptual integration, and thought remains to be accomplished. The promise of this new field, however, lies in a stunning prospect that understanding the social determinants of morbidities in childhood might unlock new approaches to the prevention and treatment of disorders over the entire life course. A final agenda for future research now outlines a set of proposals for new, promising, and possibly heuristic directions of investigation.

\section{$7 \quad$ An Agenda for Future Research}

1. As the fields reporting various forms of interplay between genes and environments exponentially grow, what is now needed are programs of research examining the questions of how and by what mechanisms genes and early social contexts co-determine trajectories of behavioral and biological development. With respect to differences in complex behavior and its disorders, a focus on proximal, neurobiological processes must come strongly to the foreground. Although pursuing the epigenetic pathogenesis of early psychiatric and other disorders is a powerful first step (Docherty and Mill 2008; Robison and Nestler 2011), it must be followed by studies examining the brain structures and neural processes that mediate GxE associations with mental and physical health (Ladd-Acosta et al. 2007; Turecki et al. 2012). As new knowledge of the 
interactive genetic and environmental influences on social brain development becomes available, a major challenge will be the integration of mechanistic observations across levels of analysis and scale (Norman et al. 2012).

2. A systematic and useful biology of social adversity will necessarily involve not only a search for the mechanisms (i.e., mediators) underpinning associations among stress, development, and morbidity but also the effects of modifiers (i.e., moderators) that reveal when, at what ages, or in what subgroups such associations hold (Baron and Kenny 1986; Kraemer et al. 2001, 2008). Understanding the mechanistic processes by which an environmental exposure is linked to disordered development can be a powerful aid to elucidating pathogenesis (e.g., the role of high-density lipoprotein transport of cholesterol as a mediator of the association between dietary fat and coronary heart disease (Lloyd et al. 2012)) and imagining novel interventions (e.g., changing mother-infant relationships as a means of altering the association between poverty and child development (Olds et al. 2010)). On the other hand, grasping mediational linkages may be a necessary but insufficient condition for understanding causation, and the parsing of populations into subgroups of varying exposure susceptibility, through the discovery of moderator variables, can also advance comprehension and the tractability of a given association (e.g., changes in the potency of stress-illness associations by differences in individual sensitivity to social contextual effects (Belsky and Pluess 2009; Boyce and Ellis 2005; Ellis et al. 2011a)).

3. As attention to epigenetic development grows, the capacity to place a finer, more exacting point on the specific kinds of environments that interact with particular allelic and epigenetic variants will be important and likely illuminating. Evolutionary perspectives on social adversity will also be essential to understand how difficult "environments of evolutionary adaptedness" shaped human and infra-human biology (e.g., Boyce and Ellis 2005; Sapolsky
2003), how contextual stressors might have generated species diversity (Wolf et al. 2005), and how adversity may have contributed to the emergence of social cooperation (Andras et al. 2007). We need far finer and more precise renditions of the social-environmental dimensions that interact with genes and produce negative and positive outcomes salient to population and public health. An important subtext to such work is the extraordinary value of cross-species, animal-human, comparative studies, which together not only inform the evolutionary biology of social environments and its consequences but also enable experimental studies capable of bolstering the causal inferences disallowed by human research.

4. Successfully pursuing a new developmental science of childhood adversity will surely also involve the perspective of complex adaptive systems. Social causation is nonlinear, rather than Newtonian, in character. Traditional epidemiologic strategies for understanding the health effects of social-environmental factors involve the ascertainment of such factors' "independent" influences on a health endpoint through the use of multiple hierarchical regression models (Diez Roux 2007). Although such an approach allows estimation of the isolated effects of single independent variables, it belies the reality that most human disorders are etiologically complex, with multiple interacting "causes." Even detecting GxE interactions almost certainly underserves the true complexity of pathogenic processes, because allelic variation in a single gene likely interacts with polymorphisms in many other genes, and multiple dimensions of the environment may also interactively influence outcomes. In such circumstances - circumstances that may eventually prove to predominate in disease causation - the use of more sophisticated models and analytic tools may be required to understand the multiply interactive networks of risk factors involved in the ontogeny of disordered development and health (Kauffman 1993; Koopman and Lynch 1999). If so, one such approach with increasingly demonstrable efficacy is the use of complex 
systems analysis, involving descriptive inventories of system components, nonlinear mathematical modeling, and the construction of agent-based models of causal networks (Diez Roux 2007; Galea et al. 2010).

5. Finally, as highlighted by Garner, Shonkoff, and others (Garner et al. 2012; Shonkoff 2012), prevention science is powerfully in need of new ideas for and approaches to the design of interventions based on the emerging science of early development. The NurseFamily Partnership program conceived and elegantly studied by David Olds and colleagues (see http://www.nursefamilypartnership.org), for example, departed dramatically from prior, outmoded early childhood enrichment programs by envisioning the motherinfant dyad as the unit of intervention and by using nurses as home visitors to effectively place the intervention within a medical frame of reference. Nonetheless, even more radical departures are needed from the conventions of traditional early development programs, including careful consideration of how complex dynamic systems thinking might be wed to novel, preventive interventions. Attending closely to discoveries emanating from the disciplines and sciences surveyed here could potentially prompt approaches to targeting and conceiving imaginative interventions with far greater efficacy and whole population effects. However complex and challenging that task might be, all such efforts could be potentially rewarded with a level of health and well-being for our children and grandchildren that is more enduring, robust, and enabling.

The new developmental biology of early life effects on health development over the life course is a now flourishing science, nearing readiness to transform conventional understandings of disease ontogeny, to foster clearer and more vivid perspectives on the temporally distant effects of childhood events, and to broaden and transform approaches to ensuring the health of our children and the developmental sturdiness of their futures. Although much careful and innovative thought will be a prerequisite for such a demanding journey, the road ahead looks promising, indeed.

\section{References}

Abbott, D. H., Keverne, E. B., Bercovitch, F. B., Shively, C. A., Mendoza, S. P., Saltzman, W., et al. (2003). Are subordinates always stressed? A comparative analysis of rank differences in cortisol levels among primates. Hormones and Behavior, 43(1), 67-82.

Adler, N. E., Boyce, W. T., Chesney, M. A., Folkman, S., \& Syme, S. L. (1993). Socioeconomic inequalities in health: No easy solution. JAMA, 269(24), 3140-3145.

Adler, N. E., Boyce, W. T., Chesney, M. A., Cohen, S., Folkman, S., Kahn, R. L., \& Syme, S. L. (1994). Socioeconomic status and health: The challenge of the gradient. The American Psychologist, 49(1), 15-24.

Adler, N. E., Epel, E. S., Castellazzo, G., \& Ickovics, J. R. (2000). Relationship of subjective and objective social status with psychological and physiological functioning: Preliminary data in healthy, White women. Health Psychology, 19(6), 586-592.

Adolphs, R. (2009). The social brain: Neural basis of social knowledge. Annual Review of Psychology, 60, 693716. doi:10.1146/annurev.psych.60.110707.163514.

Alexander, N., Klucken, T., Koppe, G., Osinsky, R., Walter, B., Vaitl, D., et al. (2012). Interaction of the serotonin transporter-linked polymorphic region and environmental adversity: Increased amygdala-hypothalamus connectivity as a potential mechanism linking neural and endocrine hyperreactivity. Biological Psychiatry, 72(1), 49-56. doi:10.1016/j.biopsych.2012.01.030.

Alkon, A., Lippert, S., Vujan, N., Rodriquez, M. E., Boyce, W. T., \& Eskenazi, B. (2006). The ontogeny of autonomic measures in 6- and 12-month-old infants. Developmental Psychobiology, 48(3), 197-208. doi:10.1002/dev.20129.

Andras, P., Lazarus, J., \& Roberts, G. (2007). Environmental adversity and uncertainty favour cooperation. BMC Evolutionary Biology, 7, 240. doi:10.1186/1471-2148-7-240.

Ariès, P. (1962). Centuries of childhood: A social history of family life. New York: Alfred A. Knopf.

Aron, E. N., Aron, A., \& Jagiellowicz, J. (2012). Sensory processing sensitivity: A review in the light of the evolution of biological responsivity. Personality and Social Psychology Review, 16(3), 262-282. doi:10.1177/1088868311434213.

Arseneault, L., Walsh, E., Trzesniewski, K., Newcombe, R., Caspi, A., \& Moffitt, T. E. (2006). Bullying victimization uniquely contributes to adjustment problems in young children: A nationally representative cohort study. Pediatrics, 118(1), 130-138. doi:10.1542/ peds.2005-2388.

Bagot, R. C., \& Meaney, M. J. (2010). Epigenetics and the biological basis of gene $\mathrm{x}$ environment interactions. Journal of the American Academy of Child and Adolescent Psychiatry, 49(8), 752-771. doi:10.1016/j. jaac.2010.06.001.

Bakermans-Kranenburg, M. J., \& Van Ijzendoorn, M. H. (2015). The hidden efficacy of interventions: Genexenvironment experiments from a differential susceptibility perspective. Annual 
Review of Psychology, 66, 381-409. doi:10.1146/ annurev-psych-010814-015407.

Bakermans-Kranenburg, M. J., Van Ijzendoorn, M. H., Mesman, J., Alink, L. R., \& Juffer, F. (2008a). Effects of an attachment-based intervention on daily cortisol moderated by dopamine receptor D4: A randomized control trial on 1- to 3-year-olds screened for externalizing behavior. Development and Psychopathology, 20(3), 805-820. doi:10.1017/S0954579408000382.

Bakermans-Kranenburg, M. J., Van Ijzendoorn, M. H., Pijlman, F. T., Mesman, J., \& Juffer, F. (2008b). Experimental evidence for differential susceptibility: Dopamine D4 receptor polymorphism (DRD4 VNTR) moderates intervention effects on toddlers' externalizing behavior in a randomized controlled trial. Developmental Psychology, 44(1), 293-300. doi:10.1037/0012-1649.44.1.293.

Barker, D. J. (1990). The fetal and infant origins of adult disease. BMJ, 301(6761), 1111.

Barker, D. J., \& Bagby, S. P. (2005). Developmental antecedents of cardiovascular disease: A historical perspective. Journal of the American Society of Nephrology, 16(9), 2537-2544. doi:10.1681/ASN.2005020160.

Baron, R., \& Kenny, D. (1986). The moderator-mediator variable distinction in social psychological research: Conceptual, strategic, and statistical considerations. Journal of Personality and Social Psychology, 51(6), 1173-1182.

Barr, R. G., Konner, M., Bakeman, R., \& Adamson, L. (1991). Crying in !Kung San infants: A test of the cultural specificity hypothesis. Developmental Medicine and Child Neurology, 33(7), 601-610.

Barr, C. S., Newman, T. K., Lindell, S., Shannon, C., Champoux, M., Lesch, K. P., et al. (2004). Interaction between serotonin transporter gene variation and rearing condition in alcohol preference and consumption in female primates. Archives of General Psychiatry, 61(11), 1146-1152.

Bateson, P., \& Gluckman, P. (2011). Plasticity, robustness, development and evolution. Cambridge CB2 8RU, UK: Cambridge University Press, The Edinburgh Building.

Bavelier, D., Levi, D. M., Li, R. W., Dan, Y., \& Hensch, T. K. (2010). Removing brakes on adult brain plasticity: From molecular to behavioral interventions. The Journal of Neuroscience, 30(45), 14964-14971.

Beckfield, J., \& Krieger, N. (2009). Epi + demos + cracy: Linking political systems and priorities to the magnitude of health inequities--evidence, gaps, and a research agenda. Epidemiologic Reviews, 31, 152177. doi:10.1093/epirev/mxp002.

Belsky, J. (2005). Differential susceptibility to rearing influence: An evolutionary hypothesis and some evidence. In B. J. Ellis \& D. F. Bjorklund (Eds.), Origins of the social mind: Evolutionary psychology and child development (pp. 139-163). New York: Guilford.

Belsky, J., \& Pluess, M. (2009). Beyond diathesis stress: Differential susceptibility to environmental influences. Psychological Bulletin, 135(6), 885-908. doi:10.1037/ a0017376.
Belsky, J., Bakermans Kranenburg, M. J., \& Van IJzendoorn, M. H. (2007). For better and for worse: Differential susceptibility to environmental influences. Current Directions in Psychological Science, 16(6), 300-304.

Blakemore, S. J. (2010). The developing social brain: Implications for education. Neuron, 65(6), 744-747. doi:10.1016/j.neuron.2010.03.004.

Blakemore, S. J. (2012). Development of the social brain in adolescence. Journal of the Royal Society of Medicine, 105(3), 111-116. doi:10.1258/jrsm.2011.110221.

Blumenshine, P., Egerter, S., Barclay, C. J., Cubbin, C., \& Braveman, P. A. (2010). Socioeconomic disparities in adverse birth outcomes: A systematic review. American Journal of Preventive Medicine, 39(3), 263-272. doi:10.1016/j.amepre.2010.05.012.

Bock, G. R., \& Whelan, J. (Eds.). (1991). The childhood environment and adult disease. West Sussez: Ciba Foundation.

Boivin, M., \& Hertzman, C. (2012). Early childhood development: Adverse experiences and developmental health. Ottawa: Royal Society of Canada.

Borghol, N., Suderman, M., McArdle, W., Racine, A., Hallett, M., Pembrey, M., et al. (2012). Associations with early life socio-economic position in adult DNA methylation. International Journal of Epidemiology, 41(1), 62-74.

Bowlby, J. (1969). Attachment and loss. London: Hogarth. Boyce, W. T. (1985). Stress and child health: An overview. Pediatric Annals, 14(8), 539-542.

Boyce, W. T. (2016). Differential susceptibility of the developing brain to contextual adversity and stress. Neuropsychopharmacology Reviews, 41(1), 142-162.

Boyce, W. T., \& Ellis, B. J. (2005). Biological sensitivity to context: I. An evolutionary-developmental theory of the origins and functions of stress reactivity. Development and Psychopathology, 17(2), 271-301.

Boyce, W. T., \& Kobor, M. S. (2015). Development and the epigenome: The 'synapse' of gene-environment interplay. Developmental Science, 18(1), 1-23. doi:10.1111/desc.12282.

Boyce, W. T., Chesney, M., Alkon-Leonard, A., Tschann, J., Adams, S., Chesterman, B., et al. (1995). Psychobiologic reactivity to stress and childhood respiratory illnesses: Results of two prospective studies. Psychosomatic Medicine, 57, 411-422.

Boyce, W. T., O'Neill-Wagner, P., Price, C. S., Haines, M., \& Suomi, S. J. (1998). Crowding stress and violent injuriesamong behaviorally inhibited rhesus macaques. Health Psychology, 17(3), 285-289.

Boyce, W. T., Den Besten, P. K., Stamperdahl, J., Zhan, L., Jiang, Y., Adler, N. E., \& Featherstone, J. D. (2010). Social inequalities in childhood dental caries: The convergent roles of stress, bacteria and disadvantage. Social Science \& Medicine, 71(9), 1644-1652. doi:10.1016/j.socscimed.2010.07.045.

Boyce, W. T., Obradović, J., Bush, N., Stamperdahl, J., Kim, Y. S., \& Adler, N. (2012a). Social stratification, classroom 'climate' and the behavioral adaptation of kindergarten children. Proceedings of the National Academy of Sciences, 109(Suppl 2), 17168-17173. 
Boyce, W. T., Sokolowski, M. B., \& Robinson, G. E. (2012b). Toward a new biology of social adversity. Proceedings of the National Academy of Sciences of the United States of America, 109(Suppl 2), 1714317148. doi:10.1073/pnas.1121264109.

Brim, O. G., \& Kagan, J. (Eds.). (1980). Constancy and change in human development. Cambridge, MA: Harvard University Press.

Bronfenbrenner, U., \& Morris, P. A. (2006). The bioecological model of human development. In R. M. Lerner \& W. Damon (Eds.), Handbook of child psychology: Vol. 1. Theoretical models of human development (6th ed., pp. 793-828). Hoboken: John Wiley \& Sons, Inc.

Brown, R. L. (2010). Epidemiology of injury and the impact of health disparities. Current Opinion in Pediatrics, 22(3), 321-325. doi:10.1097/ MOP.0b013e3283395f13.

Brown, D. W., Anda, R. F., Tiemeier, H., Felitti, V. J., Edwards, V. J., Croft, J. B., \& Giles, W. H. (2009). Adverse childhood experiences and the risk of premature mortality. American Journal of Preventive Medicine, 37(5), 389-396. doi:10.1016/j. amepre.2009.06.021.

Carpiano, R. M., Lloyd, J. E., \& Hertzman, C. (2009). Concentrated affluence, concentrated disadvantage, and children's readiness for school: A populationbased, multi-level investigation. Social Science \& Medicine, 69(3), 420-432. doi:10.1016/j. socscimed.2009.05.028.

Caspi, A., McClay, J., Moffitt, T. E., Mill, J., Martin, J., Craig, I. W., et al. (2002). Role of genotype in the cycle of violence in maltreated children. Science, 297(5582), 851-854.

Caspi, A., Sugden, K., Moffitt, T. E., Taylor, A., Craig, I. W., Harrington, H., et al. (2003). Influence of life stress on depression: Moderation by a polymorphism in the 5-HTT gene. Science, 301(5631), 386-389.

Champagne, F. A., Weaver, I. C., Diorio, J., Dymov, S., Szyf, M., \& Meaney, M. J. (2006). Maternal care associated with methylation of the estrogen receptoralpha1b promoter and estrogen receptor-alpha expression in the medial preoptic area of female offspring. Endocrinology, 147(6), 2909-2915. doi:10.1210/ en.2005-1119.

Chedgzoy, K., Greenhalgh, S., \& Shaughnessy, R. (2007). Shakespeare and childhood. Cambridge, UK: Cambridge University Press.

Chen, E., Miller, G. E., Kobor, M. S., \& Cole, S. W. (2011). Maternal warmth buffers the effects of low early-life socioeconomic status on pro-inflammatory signaling in adulthood. Molecular Psychiatry, 16(7), 729-737. doi:10.1038/mp.2010.53.

Cirulli, F., Francia, N., Berry, A., Aloe, L., Alleva, E., \& Suomi, S. J. (2009). Early life stress as a risk factor for mental health: Role of neurotrophins from rodents to non-human primates. Neuroscience and Biobehavioral Reviews, 33(4), 573-585. doi:10.1016/j. neubiorev.2008.09.001.

Cohen, S., Line, S., Manuck, S. B., Rabin, B. S., Heise, E. R., \& Kaplan, J. R. (1997). Chronic social stress, social status, and susceptibility to upper respiratory infections in nonhuman primates [see comments]. Psychosomatic Medicine, 59(3), 213-221.

Cohen, S., Janicki-Deverts, D., Chen, E., \& Matthews, K.A. (2010). Childhood socioeconomic status and adult health. Annals of the New York Academy of Sciences, 1186, 37-55. doi:10.1111/j.1749-6632.2009.05334.x.

Cole, S. W. (2009). Social regulation of human gene expression. Current DirectionsinPsychological Science, 18(3), 132-137. doi:10.1111/j.1467-8721.2009.01623.x.

Cole, S. W., Hawkley, L. C., Arevalo, J. M., Sung, C. Y., Rose, R. M., \& Cacioppo, J. T. (2007). Social regulation of gene expression in human leukocytes. Genome Biology, 8(9), R189. doi:10.1186/gb-2007-8-9-r189.

Committee on a Framework for Development a New Taxonomy of Disease. (2011). Toward precision medicine: Building a knowledge network for biomedical research and a new taxonomy of disease. Washington, DC: National Academies Press.

Cummings, E. M., El-Sheikh, M., Kouros, C. D., \& Keller, P. S. (2007). Children's skin conductance reactivity as a mechanism of risk in the context of parental depressive symptoms. Journal of Child Psychology and Psychiatry, 48(5), 436-445. doi:10.1111/j.1469-7610.2006.01713.x.

Cupello, A., Albano, C., Gatta, E., Scarrone, S., Villa, E., \& Zona, G. (2009). Binding of paroxetine to the serotonin transporter in membranes from different cells, subcellular fractions and species. Neurochemical Research, 34(2), 255-259. doi:10.1007/s11064-008-9764-z.

Curley, J. P., Jensen, C. L., Mashoodh, R., \& Champagne, F. A. (2011). Social influences on neurobiology and behavior: Epigenetic effects during development. Psychoneuroendocrinology, 36(3), 352-371. doi:10.1016/j.psyneuen.2010.06.005.

Cushing, B. S., \& Kramer, K. M. (2005). Mechanisms underlying epigenetic effects of early social experience: The role of neuropeptides and steroids. Neuroscience and Biobehavioral Reviews, 29(7), 1089-1105. doi:10.1016/j.neubiorev.2005.04.001.

Dancause, K. N., Laplante, D. P., Fraser, S., Brunet, A., Ciampi, A., Schmitz, N., \& King, S. (2012). Prenatal exposure to a natural disaster increases risk for obesity in 5(1/2)-year-old children. Pediatric Research, 71(1), 126-131. doi:10.1038/pr.2011.18.

Danese, A., Moffitt, T. E., Pariante, C. M., Ambler, A., Poulton, R., \& Caspi, A. (2008). Elevated inflammation levels in depressed adults with a history of childhood maltreatment. Archives of General Psychiatry, 65(4), 409-416.

de Quervain, D. J., Kolassa, I. T., Ackermann, S., Aerni, A., Boesiger, P., Demougin, P., et al. (2012). PKCalpha is genetically linked to memory capacity in healthy subjects and to risk for posttraumatic stress disorder in genocide survivors. Proceedings of the National Academy of Sciences of the United States of America, 109(22), 8746-8751. doi:10.1073/pnas.1200857109.

Diamond, J. (2012). The world until yesterday: What can we learn from traditional societies. New York: Penguin Group.

Diaz, C., Starfield, B., Holtzman, N., Mellits, E. D., Hankin, J., Smalky, K., \& Benson, P. (1986). Ill health 
and use of medical care: Community-based assessment of morbidity in children. Medical Care, 24(9), 848-856.

Diez Roux, A. V. (2007). Integrating social and biologic factors in health research: A systems view. Annals of Epidemiology, 17(7), 569-574. doi:10.1016/j. annepidem.2007.03.001.

Docherty, S., \& Mill, J. (2008). Epigenetic mechanisms as mediators of environmental risks for psychiatric disorders. Psychiatry, 7(12), 500-506.

Dowd, J. B., Zajacova, A., \& Aiello, A. (2009). Early origins of health disparities: Burden of infection, health, and socioeconomic status in U.S. children. Social Science \& Medicine, 68(4), 699-707. doi:10.1016/j. socscimed.2008.12.010.

Dubos, R. J. (1965). Man adapting. New Haven: Yale University Press.

Dubos, R., Savage, D., \& Schaedler, R. (1966). Biological freudianism. Lasting effects of early environmental influences. Pediatrics, 38(5), 789-800.

Dunn, E. C., Uddin, M., Subramanian, S. V., Smoller, J. W., Galea, S., \& Koenen, K. C. (2011). Research review: Gene-environment interaction research in youth depression - a systematic review with recommendations for future research. Journal of Child Psychology and Psychiatry, 52(12), 1223-1238. doi:10.1111/j.1469-7610.2011.02466.x.

Egan, S. K., \& Perry, D. G. (1998). Does low self-regard invite victimization? Developmental Psychology, 34(2), 299-309.

Egan, M. F., Goldberg, T. E., Kolachana, B. S., Callicott, J. H., Mazzanti, C. M., Straub, R. E., et al. (2001). Effect of COMT Val108/158 Met genotype on frontal lobe function and risk for schizophrenia. Proceedings of the National Academy of Sciences of the United States of America, 98(12), 6917-6922. doi:10.1073/ pnas.111134598.

Eisenberger, N. I., \& Cole, S. W. (2012). Social neuroscience and health: Neurophysiological mechanisms linking social ties with physical health. Nature Neuroscience, 15(5), 669-674. doi:10.1038/nn.3086.

Ellis, B. J., McFadyen-Ketchum, S., Dodge, K. A., Pettit, G. S., \& Bates, J. E. (1999). Quality of early family relationships and individual differences in the timing of pubertal maturation in girls: A longitudinal test of an evolutionary model. Journal of Personality and Social Psychology, 77(2), 387-401.

Ellis, B. J., Jackson, J. J., \& Boyce, W. T. (2006). The stress response systems: Universality and adaptive individual differences. Developmental Review, 26(2), 175-212.

Ellis, B. J., Boyce, W. T., Belsky, J., BakermansKranenburg, M. J., \& van Ijzendoorn, M. H. (2011a). Differential susceptibility to the environment: An evolutionary--neurodevelopmental theory. Development and Psychopathology, 23(1), 7-28. doi:10.1017/ S0954579410000611.

Ellis, B. J., Shirtcliff, E. A., Boyce, W. T., Deardorff, J., \& Essex, M. J. (2011b). Quality of early family relationships and the timing and tempo of puberty: Effects depend on biological sensitivity to context.
Development and Psychopathology, 23(1), 85-99. doi:10.1017/S0954579410000660.

El-Sheikh, M. (2005). Stability of respiratory sinus arrhythmia in children and young adolescents: A longitudinal examination. Developmental Psychobiology, 46(1), 66-74. doi:10.1002/dev.20036.

El-Sheikh, M., Keller, P. S., \& Erath, S. A. (2007). Marital conflict and risk for child maladjustment over time: Skin conductance level reactivity as a vulnerability factor. Journal of Abnormal Child Psychology, 35(5), 715-727. doi:10.1007/s10802-007-9127-2.

Essex, M. J., Thomas Boyce, W., Hertzman, C., Lam, L. L., Armstrong, J. M., Neumann, S. M., \& Kobor, M. S. (2013). Epigenetic vestiges of early developmental adversity: Childhood stress exposure and DNA methylation in adolescence. Child Development, 84(1), 58-75. doi:10.1111/j.1467-8624.2011.01641.x.

Evans, G. W. (2004). The environment of childhood poverty. The American Psychologist, 59(2), 77-92.

Evans, G. W., \& Kim, P. (2007). Childhood poverty and health: Cumulative risk exposure and stress dysregulation. Psychological Science, 18(11), 953-957. doi:10.1111/j.1467-9280.2007.02008.x.

Evans, G. W., Gonnella, C., Marcynyszyn, L. A., Gentile, L., \& Salpekar, N. (2005). The role of chaos in poverty and children's socioemotional adjustment. Psychological Science, 16(7), 560-565.

Evans, G. W., Chen, E., Miller, G., \& Seeman, T. (2012). How poverty gets under the skin: A life-course perspective. In V. Maholmes \& R. B. King (Eds.), The Oxford handbook of poverty and child development (pp. 13-36). Oxford: Oxford University Press.

Falconi, A. M., Catalano, R., \& Boyce, W. T. (2017). Early life predictors of late life health. In W. Satariano \& M. Maus (Eds.), Aging, Place, and Health: A Global Perspective. Burlington: Jones \& Bartlett Learning.

Fehr, E., Bernhard, H., \& Rockenbach, B. (2008). Egalitarianism in young children. Nature, 454(7208), 1079-1083. doi:10.1038/nature07155.

Fernald, R. D., \& Maruska, K. P. (2012). How does social information change the brain? PNAS.

Fraga, M. F., Ballestar, E., Paz, M. F., Ropero, S., Setien, F., Ballestar, M. L., et al. (2005). Epigenetic differences arise during the lifetime of monozygotic twins. Proceedings of the National Academy of Sciences of the United States of America, 102(30), 10604-10609.

Freud, S. (1940). An outline of psychoanalysis. In J. Strachey (Ed.), The standard edition of the complete psychological works of Sigmund Freud (Vol. 23). London: Hogarth Press.

Galea, S., Riddle, M., \& Kaplan, G. A. (2010). Causal thinking and complex system approaches in epidemiology. International Journal of Epidemiology, 39(1), 97-106.

Galobardes, B., Lynch, J. W., \& Davey Smith, G. (2004). Childhood socioeconomic circumstances and causespecific mortality in adulthood: Systematic review and interpretation. Epidemiologic Reviews, 26, 7-21.

Garner, A. S., Shonkoff, J. P., Siegel, B. S., Dobbins, M. I., Earls, M. F., Garner, A. S., et al. (2012). Early childhood adversity, toxic stress, and the role of the 
pediatrician: Translating developmental science into lifelong health. Pediatrics, 129(1), e224-e231. doi:10.1542/peds.2011-2662.

Gianaros, P. J., \& Manuck, S. B. (2010). Neurobiological pathways linking socioeconomic position and health. Psychosomatic Medicine, 72(5), 450-461. doi:10.1097/PSY.0b013e3181e1a23c.

Gilbert, S. F. (2002). The genome in its ecological context: Philosophical perspectives on interspecies epigenesis. Annals of the New York Academy of Sciences, 981, 202-218.

Gilbert, S. F., \& Epel, D. (2009). Ecological developmental biology: Integrating epigenetics, medicine, and evolution. Sunderland: Sinauer Associates.

Gini, G., \& Pozzoli, T. (2009). Association between bullying and psychosomatic problems: A metaanalysis. Pediatrics, 123(3), 1059-1065. doi:10.1542/ peds.2008-1215.

Glew, G. M., Fan, M. Y., Katon, W., Rivara, F. P., \& Kernic, M. A. (2005). Bullying, psychosocial adjustment, and academic performance in elementary school. Archives of Pediatrics \& Adolescent Medicine, 159(11), 10261031. doi:10.1001/archpedi.159.11.1026.

Gluckman, P. D., Hanson, M. A., \& Pinal, C. (2005). The developmental origins of adult disease. Maternal \& Child Nutrition, 1(3), 130-141.

Gluckman, P. D., Hanson, M. A., \& Beedle, A. S. (2007). Non-genomic transgenerational inheritance of disease risk. BioEssays, 29(2), 145-154.

Gluckman, P. D., Hanson, M. A., Bateson, P., Beedle, A. S., Law, C. M., Bhutta, Z. A., et al. (2009). Towards a new developmental synthesis: Adaptive developmental plasticity and human disease. Lancet, 373(9675), 1654-1657. doi:10.1016/S0140-6736(09)60234-8.

Goodman, E., Adler, N. E., Daniels, S. R., Morrison, J. A., Slap, G. B., \& Dolan, L. M. (2003). Impact of objective and subjective social status on obesity in a biracial cohort of adolescents. Obesity Research, 11(8), 1018-1026.

Gottlieb, G. (1991). Experiential canalization of behavioral development: Theory. Developmental Psychology, 27(1), 4-13.

Greenfield, E. A. (2010). Child abuse as a life-course social determinant of adult health. Maturitas, 66(1), 51-55. doi:10.1016/j.maturitas.2010.02.002.

Gump, B. B., Reihman, J., Stewart, P., Lonky, E., Darvill, T., \& Matthews, K. A. (2007). Blood lead $\mathrm{Pb})$ levels: A potential environmental mechanism explaining the relation between socioeconomic status and cardiovascular reactivity in children. Health Psychology, 26(3), 296-304. doi:10.1037/0278-6133.26.3.296.

Hackman, D. A., \& Farah, M. J. (2009). Socioeconomic status and the developing brain. Trends in Cognitive Sciences, 13(2), 65-73. doi:10.1016/j. tics.2008.11.003.

Hackman, D. A., Farah, M. J., \& Meaney, M. J. (2010). Socioeconomic status and the brain: Mechanistic insights from human and animal research. Nature Reviews Neuroscience, 11(9), 651-659. doi:10.1038/ nrn2897.
Halpern, J. (2001). From detached concern to empathy: Humanizing medical practice. New York: Oxford University Press.

Hane, A. A., \& Fox, N. A. (2006). Ordinary variations in maternal caregiving influence human infants' stress reactivity. Psychological Science, 17(6), 550-556. doi:10.1111/j.1467-9280.2006.01742.x.

Hariri, A. R., \& Weinberger, D. R. (2003). Imaging genomics. British Medical Bulletin, 65, 259-270.

Hariri, A. R., Drabant, E. M., Munoz, K. E., Kolachana, B. S., Mattay, V. S., Egan, M. F., \& Weinberger, D. R. (2005). A susceptibility gene for affective disorders and the response of the human amygdala. Archives of General Psychiatry, 62(2), 146-152.

Harlow, H. F., Harlow, M. K., \& Suomi, S. J. (1971). From thought to therapy: Lessons from a primate laboratory. American Scientist, 59(5), 538-549.

Hart, T., \& Risley, T. R. (1995). Meaningful differences in the everyday experience of young American children. Baltimore, MD: Paul H. Brookes.

Hawley, P. H. (1999). The ontogenesis of social dominance: A strategy-based evolutionary perspective. Developmental Review, 19, 97-132.

Hazani, E., \& Shasha, S. M. (2008). Effects of the Holocaust on the physical health of the offspring of survivors. The Israel Medical Association Journal, 10(4), 251-255.

Heijmans, B. T., Tobi, E. W., Stein, A. D., Putter, H., Blauw, G. J., Susser, E. S., et al. (2008). Persistent epigenetic differences associated with prenatal exposure to famine in humans. Proceedings of the National Academy of Sciences of the United States of America, 105(44), 17046-17049. doi:10.1073/pnas.0806560105.

Hensch, T. K. (2005). Critical period plasticity in local cortical circuits. Nature Reviews. Neuroscience, 6(11), 877-888. doi:10.1038/nrn1787.

Hertzman, C. (2010). Social geography of developmental health in the early years. Healthcare Quarterly, 14(1), 32-40.

Hertzman, C., \& Boyce, W. T. (2010). How experience gets under the skin to create gradients in developmental health. Annual Review of Public Health, 31, 329-347. 323p following 347. doi:10.1146/annurev. publhealth.012809.103538.

Hillis, S. D., Anda, R. F., Dube, S. R., Felitti, V. J., Marchbanks, P. A., \& Marks, J. S. (2004). The association between adverse childhood experiences and adolescent pregnancy, long-term psychosocial consequences, and fetal death. Pediatrics, 113(2), 320-327.

Houweling, T. A., \& Kunst, A. E. (2010). Socio-economic inequalities in childhood mortality in low- and middle-income countries: A review of the international evidence. British Medical Bulletin, 93, 7-26. doi:10.1093/bmb/ldp048.

Hrdy, S. B. (1999). Mother nature: Maternal instincts and how they shape the human species. New York: Ballantine Books.

Insel, T. R. (2010). The challenge of translation in social neuroscience: A review of oxytocin, vasopressin, and affiliative behavior. Neuron, 65(6), 768-779. doi:10.1016/j.neuron.2010.03.005. 
Isles, A. R., \& Wilkinson, L. S. (2008). Epigenetics: What is it and why is it important to mental disease? British Medical Bulletin, 85, 35-45. doi:10.1093/bmb/ldn004.

Janus, M., \& Offord, D. (2000). Reporting on readiness to learn at school in Canada. Canadian Journal of Policy Research, 1, 71-75.

Javidi, H., \& Yadollahie, M. (2012). Post-traumatic stress disorder. Journal of Occupational and Environmental Medicine, 3(1), 2-9.

Jirtle, R. L., \& Skinner, M. K. (2007). Environmental epigenomics and disease susceptibility. Nature Reviews. Genetics, 8(4), 253-262. doi:10.1038/nrg2045.

Kaplan, J. R., Manuck, S. B., Clarkson, T. B., Lusso, F. M., \& Taub, D. M. (1982). Social status, environment, and athersclerosis in cynomolgus monkeys. Arteriosclerosis, 2, 359-368.

Karmiloff-Smith, A. (2007). Atypical epigenesis. Developmental Science, 10(1), 84-88. doi:10.1111/j.1467-7687.2007.00568.x.

Kauffman, S. A. (1993). The origins of order: Selforganization and selection in evolution. New York: Oxford University Press.

Kawachi, I., Adler, N. E., \& Dow, W. H. (2010). Money, schooling, and health: Mechanisms and causal evidence. Annals of the New York Academy of Sciences, 1186, 56-68. doi:10.1111/j.1749-6632.2009.05340.x.

Keating, D. P., \& Hertzman, C. (1999). Developmental health and the wealth of nations: Social, biological, and educational dynamics. New York: The Guilford Press.

Keltner, D., Gruenfeld, D., \& Anderson, C. (2003). Power, approach, and inhibition. Psychological Review, 110(2), 265-284.

Kershaw, P., Forer, B., Lloyd, J. E. V., Hertzman, C., Boyce, W. T., Zumbo, B. D., et al. (2009). The use of population-level data to advance interdisciplinary methodology: A cell-through-society sampling framework for child development research. International Journal of Social Research Methodology, 12(5), 387-403.

Kessler, R. C., Duncan, G. J., Gennetian, L. A., Katz, L. F., Kling, J. R., Sampson, N. A., et al. (2014). Associations of housing mobility interventions for children in high-poverty neighborhoods with subsequent mental disorders during adolescence. JAMA, 311(9), 937-948. doi:10.1001/jama.2014.607.

Keverne, E. B., Martensz, N. D., \& Tuite, B. (1989). Beta-endorphin concentrations in cerebrospinal fluid of monkeys are influenced by grooming relationships. Psychoneuroendocrinology, 14(1-2), 155-161.

Khan, Y., \& Bhutta, Z. A. (2010). Nutritional deficiencies in the developing world: Current status and opportunities for intervention. Pediatric Clinics of North America, 57(6), 1409-1441. doi:10.1016/j. pcl.2010.09.016.

Kim, Y. S., Koh, Y. J., \& Leventhal, B. L. (2004). Prevalence of school bullying in Korean middle school students. Archives of Pediatrics \& Adolescent Medicine, 158(8), 737-741.

Kim, Y. S., Leventhal, B. L., Koh, Y. J., \& Boyce, W. T. (2009). Bullying increased suicide risk: Prospective study of Korean adolescents.
Archives of Suicide Research, 13(1), 15-30. doi:10.1080/13811110802572098.

King, M. L. (2007). Concepts of childhood: What we know and where we might go. Renaissance Quarterly, 60(2), 371-407.

Kinnally, E. L., Capitanio, J. P., Leibel, R., Deng, L., LeDuc, C., Haghighi, F., \& Mann, J. J. (2010a). Epigenetic regulation of serotonin transporter expression and behavior in infant rhesus macaques. Genes, Brain, and Behavior, 9(6), 575-582. doi:10.1111/j.1601-183X.2010.00588.x.

Kinnally, E. L., Karere, G. M., Lyons, L. A., Mendoza, S. P., Mason, W. A., \& Capitanio, J. P. (2010b). Serotonin pathway gene-gene and gene-environment interactions influence behavioral stress response in infant rhesus macaques. Development and Psychopathology, 22(1), 35-44. doi:10.1017/ S0954579409990241.

Kinnally, E. L., Feinberg, C., Kim, D., Ferguson, K., Leibel, R., Coplan, J. D., \& John Mann, J. (2011). DNA methylation as a risk factor in the effects of early life stress. Brain Behavior and Immunity. doi:10.1016/j.bbi.2011.05.001.

Kittleson, M. M., Meoni, L. A., Wang, N. Y., Chu, A. Y., Ford, D. E., \& Klag, M. J. (2006). Association of childhood socioeconomic status with subsequent coronary heart disease in physicians. Archives of Internal Medicine, 166(21), 2356-2361.

Knafo, A., Israel, S., \& Ebstein, R. P. (2011). Heritability of children's prosocial behavior and differential susceptibility to parenting by variation in the dopamine receptor D4 gene. Development and Psychopathology, 23(1), 53-67. doi:10.1017/S0954579410000647.

Koopman, J. S., \& Lynch, J. W. (1999). Individual causal models and population system models in epidemiology. American Journal of Public Health, 89(8), 1170-1174.

Kraemer, H. C., Stice, E., Kazdin, A., Offord, D., \& Kupfer, D. (2001). How do risk factors work together? Mediators, moderators, independent, overlapping and proxy-risk factors. The American Journal of Psychiatry, 158, 848-856.

Kraemer, H. C., Kiernan, M., Essex, M., \& Kupfer, D. J. (2008). How and why criteria defining moderators and mediators differ between the Baron \& Kenny and MacArthur approaches. Health Psychology, 27(2 Suppl), S101-S108. doi:10.1037/0278-6133.27.2(Suppl.).S101.

Krieger, N. (2001). Theories for social epidemiology in the 21st century: An ecosocial perspective. International Journal of Epidemiology, 30, 668-677.

Kuh, D., \& Ben-Shlomo, Y. (2004). A life course approach to chronic disease epidemiology (2nd ed.). Oxford: Oxford University Press.

Kuzawa, C. W., \& Thayer, Z. M. (2011). Timescales of human adaptation: The role of epigenetic processes. Epigenomics, 3(2), 221-234. doi:10.2217/epi.11.11.

Ladd-Acosta, C., Pevsner, J., Sabunciyan, S., Yolken, R. H., Webster, M. J., Dinkins, T., et al. (2007). DNA methylation signatures within the human brain. 
American Journal of Human Genetics, 81(6), 13041315. doi:10.1086/524110.

Lam, L. L., Emberly, E., Fraser, H. B., Neumann, S. M., Chen, E., Miller, G. E., \& Kobor, M. S. (2012). Biological and environmental predictors of variable DNA methylation in a human community cohort. PNAS.

Lawlor, D. A., Sterne, J. A., Tynelius, P., Davey Smith, G., \& Rasmussen, F. (2006). Association of childhood socioeconomic position with cause-specific mortality in a prospective record linkage study of 1,839,384 individuals. American Journal of Epidemiology, 164(9), 907-915. doi:10.1093/aje/kwj319.

Lesch, K. P. (2007). Linking emotion to the social brain. The role of the serotonin transporter in human social behaviour. EMBO Reports, 8, S24-S29. doi:10.1038/ sj.embor.7401008

Liew, C. C., Ma, J., Tang, H. C., Zheng, R., \& Dempsey, A. A. (2006). The peripheral blood transcriptome dynamically reflects system wide biology: A potential diagnostic tool. The Journal of Laboratory and Clinical Medicine, 147(3), 126-132. doi:10.1016/j. lab.2005.10.005.

Liu, L., Li, Y., \& Tollefsbol, T. O. (2008). Geneenvironment interactions and epigenetic basis of human diseases. Current Issues in Molecular Biology, 10(1-2), 25-36.

Liu, L., Johnson, H. L., Cousens, S., Perin, J., Scott, S., Lawn, J. E., et al. (2012). Global, regional, and national causes of child mortality: An updated systematic analysis for 2010 with time trends since 2000. Lancet, 379(9832), 2151-2161. doi:10.1016/ S0140-6736(12)60560-1.

Lloyd, L. J., Langley-Evans, S. C., \& McMullen, S. (2012). Childhood obesity and risk of the adult metabolic syndrome: A systematic review. International Journal of Obesity, 36(1), 1-11. doi:10.1038/ijo.2011.186.

Lumey, L. H., Stein, A. D., \& Susser, E. (2011). Prenatal famine and adult health. Annual Review of Public Health, 32, 237-262. doi:10.1146/ annurev-publhealth-031210-101230.

Lupien, S. J., King, S., Meaney, M. J., \& McEwen, B. S. (2001). Can poverty get under your skin? Basal cortisol levels and cognitive function in children from low and high socioeconomic status. Development and Psychopathology, 13, 653-676.

MacDonald, J. L., \& Roskams, A. J. (2009). Epigenetic regulation of nervous system development by DNA methylation and histone deacetylation. Progress in Neurobiology, 88(3), 170-183.

Manuck, S. B., Craig, A. E., Flory, J. D., Halder, I., \& Ferrell, R. E. (2011). Reported early family environment covaries with menarcheal age as a function of polymorphic variation in estrogen receptor-alpha. Development and Psychopathology, 23(1), 69-83. doi:10.1017/S0954579410000659.

Marmot, M. (2010). Fair society, healthy lives. Firenze: L.S. Olschki.

Mazumdar, S., King, M., Liu, K. Y., Zerubavel, N., \& Bearman, P. (2010). The spatial structure of autism in California, 1993-2001. Health \& Place, 16(3), 539546. doi:10.1016/j.healthplace.2009.12.014.
McDade, T. (2012). Early environments and the ecologics of inflammation. Proceedings of the National Academy of Sciences of the United States of America, 109(Suppl 2), 17281-17288.

McEwen, B. S., \& Gianaros, P. J. (2010). Central role of the brain in stress and adaptation: Links to socioeconomic status, health, and disease. Annals of the New York Academy of Sciences, 1186, 190-222. doi:10.1111/j.1749-6632.2009.05331.x.

McGowan, P. O., \& Szyf, M. (2010). The epigenetics of social adversity in early life: Implications for mental health outcomes. Neurobiology of Disease, 39(1), 66-72. doi:10.1016/j.nbd.2009.12.026.

McGowan, P. O., Sasaki, A., Huang, T. C., Unterberger, A., Suderman, M., Ernst, C., et al. (2008). Promoterwide hypermethylation of the ribosomal RNA gene promoter in the suicide brain. PloS One, 3(5), e2085.

McGowan, P. O., Sasaki, A., D'Alessio, A. C., Dymov, S., Labonte, B., Szyf, M., et al. (2009). Epigenetic regulation of the glucocorticoid receptor in human brain associates with childhood abuse. Nature Neuroscience, 12(3), 342-348. doi:10.1038/nn.2270.

Meaney, M. J. (2010). Epigenetics and the biological definition of gene $\mathrm{x}$ environment interactions. Child Development, 81(1), 41-79. doi:10.1111/j.1467-8624.2009.01381.x.

Meaney, M. J., \& Ferguson-Smith, A. C. (2010). Epigenetic regulation of the neural transcriptome: The meaning of the marks. Nature Neuroscience, 13(11), 1313-1318. doi:10.1038/nn1110-1313.

Mehler, M. F. (2008). Epigenetic principles and mechanisms underlying nervous system functions in health and disease. Progress in Neurobiology, 86(4), 305-341.

Miller, G. E., Chen, E., Fok, A. K., Walker, H., Lim, A., Nicholls, E. F., et al. (2009a). Low early-life social class leaves a biological residue manifested by decreased glucocorticoid and increased proinflammatory signaling. Proceedings of the National Academy of Sciences of the United States of America, 106(34), 14716-14721. doi:10.1073/pnas.0902971106.

Miller, A. H., Maletic, V., \& Raison, C. L. (2009b). Inflammation and its discontents: The role of cytokines in the pathophysiology of major depression. Biological Psychiatry, 65(9), 732-741. doi:10.1016/j. biopsych.2008.11.029.

Moffitt, T. E., Caspi, A., \& Rutter, M. (2005). Strategy for investigating interactions between measured genes and measured environments. Archives of General Psychiatry, 62(5), 473-481.

Mohr, S., \& Liew, C. C. (2007). The peripheral-blood transcriptome: New insights into disease and risk assessment. Trends in Molecular Medicine, 13(10), 422-432. doi:10.1016/j.molmed.2007.08.003.

Morita, K., Saito, T., Ohta, M., Ohmori, T., Kawai, K., Teshima-Kondo, S., \& Rokutan, K. (2005). Expression analysis of psychological stress-associated genes in peripheral blood leukocytes. Neuroscience Letters, 381(1-2), 57-62.

Msall, M. E., Bier, J. A., LaGasse, L., Tremont, M., \& Lester, B. (1998). The vulnerable preschool child: The 
impact of biomedical and social risks on neurodevelopmental function. Seminars in Pediatric Neurology, 5(1), 52-61.

Nesse, R. M., \& Young, E. A. (2000). Evolutionary origins and functions of the stress response. In G. Fink (Ed.), Encyclopedia of stress (Vol. 2, pp. 79-84). San Diego: Academic Press.

Norman, G. J., Hawkley, L. C., Cole, S. W., Berntson, G. G., \& Cacioppo, J. T. (2012). Social neuroscience: The social brain, oxytocin, and health. Social Neuroscience, 7(1), 18-29. doi:10.1080/17470919.2 011.568702 .

Oberg, C. (2008). Children of genocide: A legacy of lost dreams. Pediatrics, 121(3), 611-615. doi:10.1542/ peds.2007-2208.

Oberlander, T. F., Weinberg, J., Papsdorf, M., Grunau, R., Misri, S., \& Devlin, A. M. (2008). Prenatal exposure to maternal depression, neonatal methylation of human glucocorticoid receptor gene (NR3C1) and infant cortisol stress response. Epigenetics, 3(2), 97-106.

Obradovic, J., Bush, N. R., Stamperdahl, J., Adler, N. E., \& Boyce, W. T. (2010). Biological sensitivity to context: The interactive effects of stress reactivity and family adversity on socio-emotional behavior and school readiness. Child Development, 81(1), 270-289.

Offord, D. R. (1995). Child psychiatric epidemiology: Current status and future prospects. Canadian Journal of Psychiatry. Revue Canadienne de Psychiatrie, 40(6), 284-288.

Olds, D. L., Kitzman, H. J., Cole, R. E., Hanks, C. A., Arcoleo, K. J., Anson, E. A., et al. (2010). Enduring effects of prenatal and infancy home visiting by nurses on maternal life course and government spending: Follow-up of a randomized trial among children at age 12 years. Archives of Pediatrics and Adolescent Medicine, 164(5), 419-424. doi:10.1001/ archpediatrics.2010.49.

Ollikainen, M., Smith, K. R., Joo, E. J., Ng, H. K., Andronikos, R., Novakovic, B., et al. (2010). DNA methylation analysis of multiple tissues from newborn twins reveals both genetic and intrauterine components to variation in the human neonatal epigenome. Human Molecular Genetics, 19(21), 4176-4188. doi: $10.1093 / \mathrm{hmg} / \mathrm{ddq} 336$.

Ostrove, J. M., Adler, N. E., Kuppermann, M., \& Washington, A. E. (2000). Objective and subjective assessments of socioeconomic status and their relationship to self-rated health in an ethnically diverse sample of pregnant women. Health Psychology, 19(6), 613-618.

Overton, W. F., \& Lerner, R. M. (2014). Fundamental concepts and methods in developmental science: A relational perspective. Research in Human Development, $11,63-73$.

Painter, R. C., Roseboom, T. J., \& Bleker, O. P. (2005). Prenatal exposure to the Dutch famine and disease in later life: An overview. Reproductive Toxicology, 20(3), 345-352.

Painter, R., Osmond, C., Gluckman, P., Hanson, M., Phillips, D., \& Roseboom, T. (2008). Transgenerational effects of prenatal exposure to the Dutch famine on neonatal adiposity and health in later life. BJOG: An International Journal of Obstetrics \& Gynaecology, 115(10), 1243-1249.

Panter-Brick, C., Lende, D., \& Kohrt, B. (2012). Children in global adversity: Physical health, mental health, behavioral health, and symbolic health. In V. Maholmes \& R. B. King (Eds.), The Oxford handbook of poverty and child development (pp. 603-621). Oxford: Oxford University Press.

Pellegrini, A. D., Roseth, C. J., Mliner, S., Bohn, C. M., Van Ryzin, M., Vance, N., et al. (2007). Social dominance in preschool classrooms. Journal of Comparative Psychology, 121(1), 54-64. doi:10.1037/0735-7036.121.1.54.

Pellegrini, A. D., Van Ryzin, M. J., Roseth, C., BohnGettler, C., Dupuis, D., Hickey, M., \& Peshkam, A. (2010). Behavioral and social cognitive processes in preschool children's social dominance. Aggressive Behavior, 37(3), 248-257. doi:10.1002/ab.20385.

Pezawas, L., Meyer-Lindenberg, A., Drabant, E. M., Verchinski, B. A., Munoz, K. E., Kolachana, B. S., et al. (2005). 5-HTTLPR polymorphism impacts human cingulate-amygdala interactions: A genetic susceptibility mechanism for depression. Nature Neuroscience, 8(6), 828-834.

Pluess, M., \& Belsky, J. (2013). Vantage sensitivity: Individual differences in response to positive experiences. Psychological Bulletin, 139(4), 901-916. doi:10.1037/a0030196.

Quas, J.A., Bauer, A., \& Boyce, W. T. (2004). Physiological reactivity, social support, and memory in early childhood. Child Development, 75(3), 797-814.

Rifkin, J. (2009). The empathic civilization: The race to global consciousness in a world in crisis. New York: Jeremy P. Tarcher/Penguin.

Robert Wood Johnson Foundation Commission to Build a Healthier America. (2009). Beyond Health Care: New Directions to a Healthier America. Retrieved from Princeton, $\mathrm{NJ}$ :

Robinson, G. E., Grozinger, C. M., \& Whitfield, C. W. (2005). Sociogenomics: Social life in molecular terms. Nature Reviews Genetics, 6, 257-270.

Robinson, G. E., Fernald, R. D., \& Clayton, D. F. (2008). Genes and social behavior. Science, 322(5903), 896900. doi:10.1126/science.1159277.

Robison, A. J., \& Nestler, E. J. (2011). Transcriptional and epigenetic mechanisms of addiction. Nature Reviews. Neuroscience, 12(11), 623-637. doi:10.1038/nrn3111.

Roseboom, T. J., van der Meulen, J. H., Osmond, C., Barker, D. J., Ravelli, A. C., Schroeder-Tanka, J. M., et al. (2000). Coronary heart disease after prenatal exposure to the Dutch famine, 1944-45. Heart, 84(6), 595-598.

Roth, T. L., Lubin, F. D., Funk, A. J., \& Sweatt, J. D. (2009). Lasting epigenetic influence of early-life adversity on the BDNF gene. Biological Psychiatry, 65(9), 760-769. doi:10.1016/j.biopsych.2008.11.028.

Russo, V. E. A., Cove, D. J., Edgar, L. G., Jaenisch, R., \& Salamini, F. (Eds.). (1999). Development: Genetics, epigenetics and environmental regulation. Berlin: Springer-Verlag. 
Rutter, M. (2006). Genes and behaviour: Nature/nurture interplay explained. Oxford, UK: Blackwell Publishing.

Rutter, M. (2012). Achievements and challenges in the biology of environmental effects. PNAS.

Sapolsky, R. M. (2003). Stress and plasticity in the limbic system. Neurochemical Research, 28(11), 1735-1742.

Sapolsky, R. M. (2005). The influence of social hierarchy on primate health. Science, 308(5722), 648-652.

Schneider, J., Dickinson, M., \& Levine, J. (2012). Social structures depend on innate determinants and chemosensory processing in Drosophila. PNAS.

Sentenac, M., Arnaud, C., Gavin, A., Molcho, M., Gabhainn, S. N., \& Godeau, E. (2012). Peer victimization among school-aged children with chronic conditions. Epidemiologic Reviews, 34(1), 120-128. doi:10.1093/epirev/mxr024.

Shannon, K. E., Beauchaine, T. P., Brenner, S. L., Neuhaus, E., \& Gatzke-Kopp, L. (2007). Familial and temperamental predictors of resilience in children at risk for conduct disorder and depression. Development and Psychopathology, 19(3), 701-727. doi:10.1017/ S0954579407000351.

Shonkoff, J. (2012). Leveraging the biology of adversity and resilience to address the roots of disparities in health and development. Proceedings of the National Academy of Sciences of the United States of America,109(Suppl 2), 17302-17307.

Shonkoff, J. P., \& Garner, A. S. (2012). The lifelong effects of early childhood adversity and toxic stress. Pediatrics, 129(1), e232-e246. doi:10.1542/ peds.2011-2663.

Shonkoff, J. P., \& Phillips, D. A. (Eds.). (2000). From neurons to neighborhoods: The science of early child development. Washington, DC: National Academy Press.

Shorter, E. (1975). The making of the modern family. New York: Basic Books.

Slavich, G. M., \& Cole, S. W. (2013). The emerging field of human social genomics. Clinical Psychological Science: A Journal of the Association for Psychological Science, 1(3), 331-348.

Sourander, A., Jensen, P., Ronning, J. A., Elonheimo, H., Niemela, S., Helenius, H., et al. (2007). Childhood bullies and victims and their risk of criminality in late adolescence: The Finnish From a Boy to a Man study. Archives of Pediatrics \& Adolescent Medicine, 161(6), 546-552. doi:10.1001/archpedi.161.6.546.

Stearns, P. N. (2011). Childhood in world history (2nd ed.). New York, NY: Routledge.

Steptoe, A., Feldman, P. J., Kunz, S., Owen, N., Willemsen, G., \& Marmot, M. (2002). Stress responsivity and socioeconomic status: A mechanism for increased cardiovascular disease risk? European Heart Journal, 23, 1757-1763.

Stevens, H. E., Leckman, J. F., Coplan, J. D., \& Suomi, S. J. (2009). Risk and resilience: Early manipulation of macaque social experience and persistent behavioral and neurophysiological outcomes.
Journal of the American Academy of Child and Adolescent Psychiatry, 48(2), 114-127. doi:10.1097/ CHI.0b013e318193064c.

Suomi, S. J. (2006). Risk, resilience, and gene x environment interactions in rhesus monkeys. Annals of the New York Academy of Sciences, 1094, 52-62. doi:10.1196/annals.1376.006.

Syme, S. L. (2008). Reducing racial and social-class inequalities in health: The need for a new approach. Health Affairs (Millwood), 27(2), 456-459. doi:10.1377/hlthaff.27.2.456.

Szyf, M., McGowan, P., \& Meaney, M. J. (2008). The social environment and the epigenome. Environmental and Molecular Mutagenesis, 49(1), 46-60. doi:10.1002/ em.20357.

Thompson, P. M., Martin, N. G., \& Wright, M. J. (2010). Imaging genomics. Current Opinion in Neurology, 23(4), 368-373. doi:10.1097/ WCO.0b013e32833b764c.

Tsankova, N., Renthal, W., Kumar, A., \& Nestler, E. J. (2007). Epigenetic regulation in psychiatric disorders. Nature Reviews. Neuroscience, 8(5), 355-367. doi: $10.1038 / \mathrm{nrn} 2132$.

Turecki, G., Ernst, C., Jollant, F., Labonte, B., \& Mechawar, N. (2012). The neurodevelopmental origins of suicidal behavior. Trends in Neurosciences, 35(1), 14-23. doi:10.1016/j.tins.2011.11.008.

Turner, J. D., Pelascini, L. P., Macedo, J. A., \& Muller, C. P. (2008). Highly individual methylation patterns of alternative glucocorticoid receptor promoters suggest individualized epigenetic regulatory mechanisms. Nucleic Acids Research, 36(22), 7207-7218. doi:10.1093/nar/gkn897.

Turner, H. A., Finkelhor, D., Shattuck, A., \& Hamby, S. (2012). Recent victimization exposure and suicidal ideation in adolescents. Archives of Pediatrics \& Adolescent Medicine, 1-6. doi:10.1001/ archpediatrics.2012.1549.

U.S. Department of Health and Human Services. (2011). CDC Health Disparities and Inequalities ReportUnited States, 2011. Atlanta: U.S. Department of Health and Human Services, Centers for Disease Control and Prevention.

Uebelhack, R., Franke, L., Herold, N., Plotkin, M., Amthauer, H., \& Felix, R. (2006). Brain and platelet serotonin transporter in humans-correlation between [123I]-ADAM SPECT and serotonergic measurements in platelets. Neuroscience Letters, 406(3), 153158. doi:10.1016/j.neulet.2006.06.004.

van IJzendoorn, M. H., Caspers, K., BakermansKranenburg, M. J., Beach, S. R., \& Philibert, R. (2010). Methylation matters: Interaction between methylation density and serotonin transporter genotype predicts unresolved loss or trauma. Biological Psychiatry, 68(5), 405-407. doi:10.1016/j.biopsych.2010.05.008.

Vogel, E. F., \& Bell, N. W. (1961). The emotionally disturbed child as the family scapegoat. In N. W. Bell \& E. F. Vogel (Eds.), A Modern introduction to the family. London: Routledge \& Kegan Paul. 
Waddington, C. H. (1959). Canalization of development and genetic assimilation of acquired characters. Nature, 183(4676), 1654-1655.

Waddington, C. H. (2012). The epigenotype. 1942. International Journal of Epidemiology, 41(1), 10-13. doi:10.1093/ije/dyr184.

Wadsworth, M. E., Raviv, T., Reinhard, C., Wolff, B., Santiago, C. D. C., \& Einhorn, L. (2008). An indirect effects model of the association between poverty and child functioning: The role of children. Journal of Loss and Trauma, 30.

Weaver, I. C. (2009). Epigenetic effects of glucocorticoids. Seminars in Fetal and Neonatal Medicine, 14(3), 143-150. doi:10.1016/j.siny.2008.12.002.

Weaver, I. C., Cervoni, N., Champagne, F. A., D'Alessio, A. C., Sharma, S., Seckl, J. R., et al. (2004). Epigenetic programming by maternal behavior. Nature Neuroscience, 7(8), 847-854.

Weikum, W. M., Oberlander, T. F., Hensch, T. K., \& Werker, J. F. (2012). Prenatal exposure to antidepressants and depressed maternal mood alter trajectory of infant speech perception. Proceedings of the National Academy of Sciences, 109(2), 17221-17227. doi:10.1073/pnas.1121263109.

West-Eberhard, M. J. (2003). Developmental plasticity and evolution. New York: Oxford University Press.
Whittle, S., Yap, M. B., Sheeber, L., Dudgeon, P., Yucel, M., Pantelis, C., et al. (2010). Hippocampal volume and sensitivity to maternal aggressive behavior: A prospective study of adolescent depressive symptoms. Development and Psychopathology, 23(1), 115-129. doi:10.1017/S0954579410000684.

Wolf, D. M., Vazirani, V. V., \& Arkin, A. P. (2005). Diversity in times of adversity: Probabilistic strategies in microbial survival games. Journal of Theoretical Biology, 234(2), 227-253. doi:10.1016/j. jtbi.2004.11.020.

Wright, R. O., \& Christiani, D. (2010). Gene-environment interaction and children's health and development. Current Opinion in Pediatrics, 22(2), 197-201. doi:10.1097/MOP.0b013e328336ebf9.

Wu, H., \& Sun, Y. E. (2006). Epigenetic regulation of stem cell differentiation. Pediatric Research, 59(4 Pt 2), 21R-25R. doi:10.1203/01.pdr.0000203565.76028.2a.

Yang, E.-J., Lin, E. W., \& Hensch, T. K. (2012). A critical period for acoustic preference in mice. Proceedings of the National Academy of Sciences, 109(Suppl 2), 17213-17220.

Zhang, T. Y., \& Meaney, M. J. (2010). Epigenetics and the environmental regulation of the genome and its function. Annual Review of Psychology, 61, 439-466, C431-433.. doi:10.1146/annurev. psych.60.110707.163625.

Open Access This chapter is licensed under the terms of the Creative Commons Attribution 4.0 International License (http://creativecommons.org/licenses/by/4.0/), which permits use, sharing, adaptation, distribution and reproduction in any medium or format, as long as you give appropriate credit to the original author(s) and the source, provide a link to the Creative Commons license and indicate if changes were made.

The images or other third party material in this chapter are included in the chapter's Creative Commons license, unless indicated otherwise in a credit line to the material. If material is not included in the chapter's Creative Commons license and your intended use is not permitted by statutory regulation or exceeds the permitted use, you will need to obtain permission directly from the copyright holder. 